\title{
Modeling a typical winter-time dust event over the Arabian Peninsula and the Red Sea
}

\author{
S. Kalenderski ${ }^{1}$, G. Stenchikov ${ }^{1}$, and C. Zhao $^{2}$ \\ ${ }^{1}$ Division of Physical Sciences and Engineering, King Abdullah University of Science and Technology, Thuwal, Saudi Arabia \\ ${ }^{2}$ Atmospheric Sciences and Global Change Division, Pacific Northwest National Laboratory, Richland, WA, USA
}

Correspondence to: S. Kalenderski (stoitchko.kalenderski@kaust.edu.sa)

Received: 2 August 2012 - Published in Atmos. Chem. Phys. Discuss.: 9 October 2012

Revised: 24 January 2013 - Accepted: 7 February 2013 - Published: 20 February 2013

\begin{abstract}
We used WRF-Chem, a regional meteorological model coupled with an aerosol-chemistry component, to simulate various aspects of the dust phenomena over the Arabian Peninsula and Red Sea during a typical winter-time dust event that occurred in January 2009. The model predicted that the total amount of emitted dust was $18.3 \mathrm{Tg}$ for the entire dust outburst period and that the two maximum daily rates were $\sim 2.4 \mathrm{Tg} \mathrm{day}^{-1}$ and $\sim 1.5 \mathrm{Tg} \mathrm{day}^{-1}$, corresponding to two periods with the highest aerosol optical depth that were well captured by ground- and satellite-based observations. The model predicted that the dust plume was thick, extensive, and mixed in a deep boundary layer at an altitude of 3-4 km. Its spatial distribution was modeled to be consistent with typical spatial patterns of dust emissions. We utilized MODIS-Aqua and Solar Village AERONET measurements of the aerosol optical depth (AOD) to evaluate the radiative impact of aerosols. Our results clearly indicated that the presence of dust particles in the atmosphere caused a significant reduction in the amount of solar radiation reaching the surface during the dust event. We also found that dust aerosols have significant impact on the energy and nutrient balances of the Red Sea. Our results showed that the simulated cooling under the dust plume reached $100 \mathrm{~W} \mathrm{~m}^{-2}$, which could have profound effects on both the sea surface temperature and circulation. Further analysis of dust generation and its spatial and temporal variability is extremely important for future projections and for better understanding of the climate and ecological history of the Red Sea.
\end{abstract}

\section{Introduction}

Mineral dust produced by wind erosion is an important factor in the earth-atmosphere-ocean system. It directly affects the earth's energy budget (Ackermann and Chung, 1992; Seinfeld et al., 2004; Ge et al., 2010; Zhao et al., 2011) by scattering and absorbing radiation; it indirectly affects the energy budget by modifying the microphysics of the clouds (Satheesh and Moorthy, 2005; Haywood and Boucher, 2000). Mineral dust makes important contributions to the fertilization of phytoplankton through ocean deposition and thus to carbon dioxide levels in the atmosphere (Watson et al., 2000; Johnson et al., 2011). Additionally, dust has substantial impacts on the hydrological cycle (Miller et al., 2004; Zhao et al., 2011, 2012) and many biogeochemical cycles by providing reaction sites and carrying many condensed and absorbed species (Dentener et al., 1996; Huebert et al., 2003).

The MENA region (Middle East and North Africa at 0 $40^{\circ} \mathrm{N}$ and $15^{\circ} \mathrm{W}-60^{\circ} \mathrm{E}$ ) is the world's major dust source and accounts for about half of global dust emissions (Prospero et al., 2002). On a global scale, total dust emissions are estimated to be in the range of about 1000 to $2000 \mathrm{Tg} \mathrm{yr}^{-1}$ (Zender et al., 2004); the contribution from MENA would thus be about 500 to $1000 \mathrm{Tg}^{-1}$. MENA is subject to strong winds that can carry substantial quantities of finer dust particles over huge distances of about $1000 \mathrm{~km}$ or more from the source. For example, each summer large amounts of mineral dust from the Arabian Peninsula and North Africa are transported across the northern Indian Ocean ( $\mathrm{Li}$ and $\mathrm{Ra}-$ manathan, 2002) while dust from the Sahara may reach North America (McKendry et al., 2007). Saharan dust is also a major source of the dust deposited into the Mediterranean 
Sea and neighboring countries (Santese et al., 2007; Avila et al., 1997). Because of the great distances over which dust plumes can be transported and the large amount of dust injected into the atmosphere, MENA dust has global implications in terms of climate change and biogeochemical cycling. Although much work has investigated the impact of MENA dust on the global scale and on the regional scale over West North Africa (WNA), little has been done to investigate dust transport within the MENA region and its regional impact over the Arabian Peninsula, Red Sea and East North Africa (ENA). Numerical models allow us to integrate our knowledge of various atmospheric processes and to study their interactions. In this study, we used the Weather Research and Forecast model (Skamarock et al., 2008) coupled with the chemistry module (WRF-Chem; Grell et al., 2005) to investigate dust transport from the Arabian Peninsula across the Red Sea and the regional impact of dust aerosols. The satellite observations show that Arabian dust transport over the Red Sea is typical for winter time. This is consistent with the frequently observed strong surface winds in this area. Jiang et al. (2009) reported that the wintertime westwardblowing wind-jet bands along the northwestern coast of Arabian Peninsula occur every 10-20 days and can last for several days when occurring. Here we attempted to quantify the various effects of a dust event that occurred in January 2009. The model results were compared with groundbased Aerosol Robotic Network (AERONET, Holben et al., 1998) measurements and satellite-based Moderate Resolution Imaging Spectroradiometer (MODIS, Salomonson et al., 1989) observations.

The remainder of this paper is organized as follows. In Sect. 2, we present the model description and describe the experimental domain. Section 3 describes the ground- and satellite-based observations. Dust emissions, spatial and vertical distributions, optical properties and heating rates, impact of dust on the radiative budget, surface heat fluxes and temperature, deposition as well as the impact of dust on the Red Sea are discussed in the Sect. 4. Finally, we summarize our work and draw conclusions in the Sect. 5.

\section{Model}

\subsection{Model description}

The WRF model is a state-of-the-art numerical weather prediction system designed to simulate atmospheric processes for both research and operational applications (Skamarock et al., 2008). The model has been used to simulate atmospheric processes over a wide range of spatial and temporal scales. WRF is based on fully compressible nonhydrostatic NavierStokes equations that describe atmospheric flow. The model uses a generalized vertical terrain-following coordinate system and takes into account a variety of physical processes such as boundary layer meteorology, deep and shallow convection, radiation, and land surface processes.

WRF-Chem is an extended version of the WRF model that includes a chemistry component (Grell et al., 2005) and has been widely used for air quality and regional climate studies (Fast et al., 2006, 2009; Zhao et al., 2010, 2011, and 2012; Zhang et al., 2009). The chemistry component is fully coupled with the meteorological model and both components use the same transport scheme, integration grid, physics parameterizations, and time steps. Additionally, the chemistry component takes into account a variety of coupled physical and chemical processes such as transport, deposition, chemical transformations, aerosol interactions, photolysis, radiation, and emissions.

\subsection{Model configuration and experimental domain}

The WRF framework comprises various parameterizations of unresolved sub-grid-scale physical processes, which allow the model to be used over a wide range of spatial and temporal scales. In this study, we have chosen the Mellor-YamadaJanjic (MYJ) (Janjic, 2002) planetary boundary layer scheme to parameterize the boundary layer processes. We selected the Rapid Radiative Transfer Model (RRTM) (Mlawer et al., 1997) to represent longwave and shortwave radiation transfer within the atmosphere and the surface. In the model, the Lin microphysics scheme (Lin et al., 1983) accounts for nonconvective precipitation processes and the Grell convective scheme (Grell and Devenyi, 2002) captures cumulous cloud parameterizations. The NOAH Land Surface model (Chen and Dudhia, 2001) and the Janjic Eta surface layer scheme (Janjic, 1996) provide surface processes calculations. Additionally, National Centers for Environmental Prediction's (NCEP) global final analysis (FNL) is used to prepare the lateral boundary and initial conditions for the meteorological fields and NCEP's daily global sea surface temperature (SST) analysis (RTG_SST_HR) is used to update SST every six hours.

Version 3.3.1 of the air quality component WRF-Chem used here was configured with the RADM2 (Regional Acid Deposition Model 2) photochemical mechanism (Stockwell et al., 1990), the Fast-J photolysis scheme, and the MADE/SORGAM (Modal Aerosol Dynamics Model for Europe (MADE) and Secondary Organic Aerosol Model (SORGAM)) aerosol model (Ackerman et al., 1998; Schell et al., 2001). Initial and boundary conditions for aerosol and gas-phase species were from the default WRF-Chem profiles. These WRF-Chem profiles were obtained from various field studies to represent clean atmosphere, maritime, midlatitude conditions (McKeen et al., 2002). Anthropogenic emissions were provided by the REanalysis of the TROpospheric (RETRO) chemical composition inventories (http:// retro.enes.org/index.shtml) and by the Emission Database for Global Atmospheric Research (EDGAR, http://edgar.jrc.ec. europa.eu). Biomass burning emissions were obtained from 
the Global Fire Emissions Database, Version 2 (GFEDv2.1) (Randerson et al., 2005) with a $1^{\circ} \times 1^{\circ}$ spatial resolution and an 8-day temporal resolution. All emission inventories were preprocessed by the PREP-CHEM-SRC v1 emissions preprocessor (Freitas et al., 2011). Biogenic emissions were not included in this study. Additionally, the GOCART (Global Ozone Chemistry Aerosol Radiation and Transport) dust emission scheme was coupled with the MADE/SORGAM aerosol model to account for the dust emission processes. The GOCART scheme (Ginoux et al., 2001) calculates the dust emission flux for particle size class $p$ by the expression:

$F_{\mathrm{p}}= \begin{cases}C S s_{\mathrm{p}} u_{10 \mathrm{~m}}^{2}\left(u_{10 \mathrm{~m}}-u_{\mathrm{t}}\right) & \text { if } u_{10 \mathrm{~m}}>u_{\mathrm{t}} \\ 0 & \text { otherwise }\end{cases}$

where $C$ is an empirical proportionality constant, $S$ is the source function with a $0.25^{\circ} \times 0.25^{\circ}$ spatial resolution, $u_{10 \mathrm{~m}}$ is the horizontal wind speed at the altitude of $10 \mathrm{~m}, u_{\mathrm{t}}$ is the threshold velocity, which is function of particle size, air density, and surface moisture, $s_{\mathrm{p}}$ is the fraction of each size class of dust in the emission. For this simulation, the value of $C$ was tuned to $0.4 \times 10^{-9} \mathrm{~kg} \mathrm{~s}^{2} \mathrm{~m}^{-5}$ to be consistent with measurements at the Solar Village AERONET station, located in the eastern part of Saudi Arabia. The original GOCART emission scheme is an 8 size bins model which does not calculate lognormal size distribution parameters of emitted dust required by the aerosol and the optical properties modules. Therefore, the scheme is used to calculate the total dust mass fluxes and the parameters of the size distribution of the emitted dust are estimated during the simulation. For details describing the GOCART dust emission scheme in WRF-Chem and selecting the value of $C$, see Zhao et al. (2010).

The experimental domain covered the Arabian Peninsula, the Red Sea, and eastern part of North Africa, an area from $30^{\circ} \mathrm{E}$ to $60^{\circ} \mathrm{E}$ in longitude and from $5^{\circ} \mathrm{N}$ to $32^{\circ} \mathrm{N}$ in latitude centered at $\left(18^{\circ} \mathrm{E} ; 45^{\circ} \mathrm{N}\right)$, with $330 \times 297$ grid points, a $10 \mathrm{~km}$ horizontal resolution, and 40 vertical layers up to $10 \mathrm{hPa}$. The simulation was performed for a period extending from 1 to 20 January 2009, which included several major dust outbreaks from the Arabian Peninsula across the Red Sea. The impact from the initial conditions was reduced by applying a six-day spin-up period and simulated results only from 7 to 20 January were used. The radiative impacts were evaluated using two parallel simulations, one including radiative feedback of the dust and the other without it.

\section{Observations and measurements}

\subsection{AERONET data}

AERONET is a ground-based remote sensing aerosol network initiated by NASA to measure the optical properties of aerosols and validate satellite retrievals. It uses CIMEL sun and sky radiometers, which are automatic robotically op- erated instruments located across the world. Aerosol products are routinely retrieved from AERONET raw data following the approach described by Dubovik and King (2000) and Dubovik et al. (2000). In this study, AERONET version 2, level 1.5 cloud-screened data were employed throughout the analysis of the optical properties of aerosols since level-2 quality-assured data were not available. For comparison of the optical properties from the model output at $600 \mathrm{~nm}$ wavelength and the AERONET measurements, the Angstrom power law was used:

$$
X(600)=X(675) \times\left(\frac{600}{675}\right)^{-\alpha},
$$

where $\alpha$ is the Angstrom exponent provided by the AERONET measurements and given by

$\alpha=\ln \left(\frac{X(440)}{X(675)}\right) / \ln \left(\frac{675}{440}\right)$

and $X$ is an aerosol optical property. The uncertainty of AOD at $600 \mathrm{~nm}$ under cloud-free conditions is less then \pm 0.01 (Holben et al., 1998). Simulated data were taken on the same time basis as the measurements.

\subsection{MODIS data}

MODIS is a multidisciplinary instrument on board the NASA Terra and Aqua satellites (Salomonson et al., 1989) designed to measure biological and physical processes including clouds and aerosols in the atmosphere, land coverage, sea surface temperature, etc. Polar orbiting MODIS instruments view the entire Earth's surface every one to two days, acquiring data from a large spectral range (36 channels between 405 and $14385 \mathrm{~nm})$, with high spatial resolution $(250 \mathrm{~m}$ at the nadir), and across a wide swath $(2330 \mathrm{~km})$. The channels between 400 and $2100 \mathrm{~nm}$ are suitable for retrieving aerosol properties. The MODIS aerosol products are derived operationally based on three independent algorithms (Remer et al., 2008), two of which derive aerosol properties over land and the other over the ocean. The standard land algorithm is based on the "dark target" approach (King et al., 1992; Kaufman et al., 1997) and consequently does not retrieve aerosol information over bright surfaces such as deserts, ice, and snow. The second land algorithm, "Deep Blue" (Hsu et al., 2004), alleviates the bright-surface problem by employing radiance measurements from the blue channels to infer the properties of aerosols. Its results are therefore used in this study. Deep Blue (Collection 051) daily, level 2, data, available only from MODIS on the Aqua satellite, are used in combination with the standard ocean algorithm (Tanre et al., 1997) for comparison with simulated aerosol properties.

The uncertainties for MODIS AOD products are usually characterized by comparing with the AERONET AOD measurements. Remer et al. (2008) found that MODIS AOD retrievals fell within expected error more than $60 \%$ 


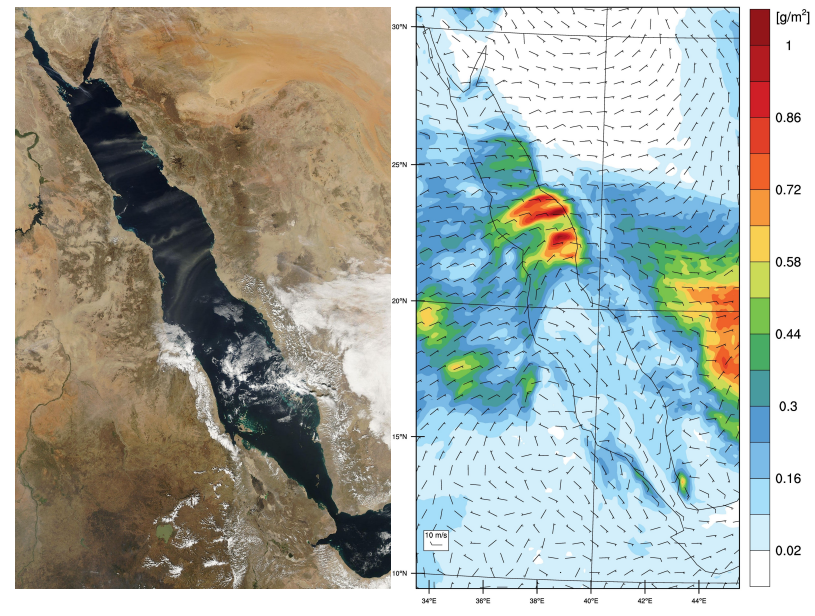

Fig. 1. An image taken by Aqua/MODIS over the Red Sea at 10:55 UTC on 14 January (left panel) and the WRF-Chem's column integrated dust load $\left[\mathrm{g} \mathrm{m}^{-2}\right.$ ] prediction and $10 \mathrm{~m}$ wind vector fields for 11:00 UTC on 14 January (right panel).

of the time over the ocean and more than $72 \%$ of the time over the land. The expected error depends on total AOD reaching $\pm(0.03+0.05 \cdot A O D)$ over the ocean and $\pm(0.03+0.15 \cdot \mathrm{AOD})$ over the land.

\section{Results and discussion}

An image of the Red Sea taken by the Aqua MODIS satellite at 10:55 UTC on 14 January and the WRF-Chem predicted dust load field for 11:00 UTC on 14 January are shown in Fig. 1. For the comparison between the satellite observations and simulations, the model domain (Fig. 1, right panel) was spatially restricted to match the region covered by the MODIS image. The clear MODIS image (Fig. 1, left panel) presents a rare opportunity to use visual confirmation to conduct model analysis of mineral dust transport from the Arabian Peninsula across the Red Sea. Figure 1 confirms that the model correctly simulates the spatial pattern of dust plume over the Red Sea. In addition, since the wind field is the main factor in the calculation of dust emissions, we also compared the modeled $10 \mathrm{~m}$ wind speed with the $10 \mathrm{~m}$ wind field from ECMWF (European Center for Medium-Range Weather Forecast) Interim global reanalysis. The model and reanalysis fields are well correlated, both time averaged and instantaneous, with correlation coefficient of 0.81 and 0.62 , respectively (see Fig. 2). The model uses higher spatial resolution than the reanalysis and therefore can better capture the fine-scale features of the flow. As can be seen in Fig. 2, the model is able to reproduce the westward-blowing wind jets along the coast at the north part of Red Sea and thus depicts the Arabian dust transport observed in the MODIS
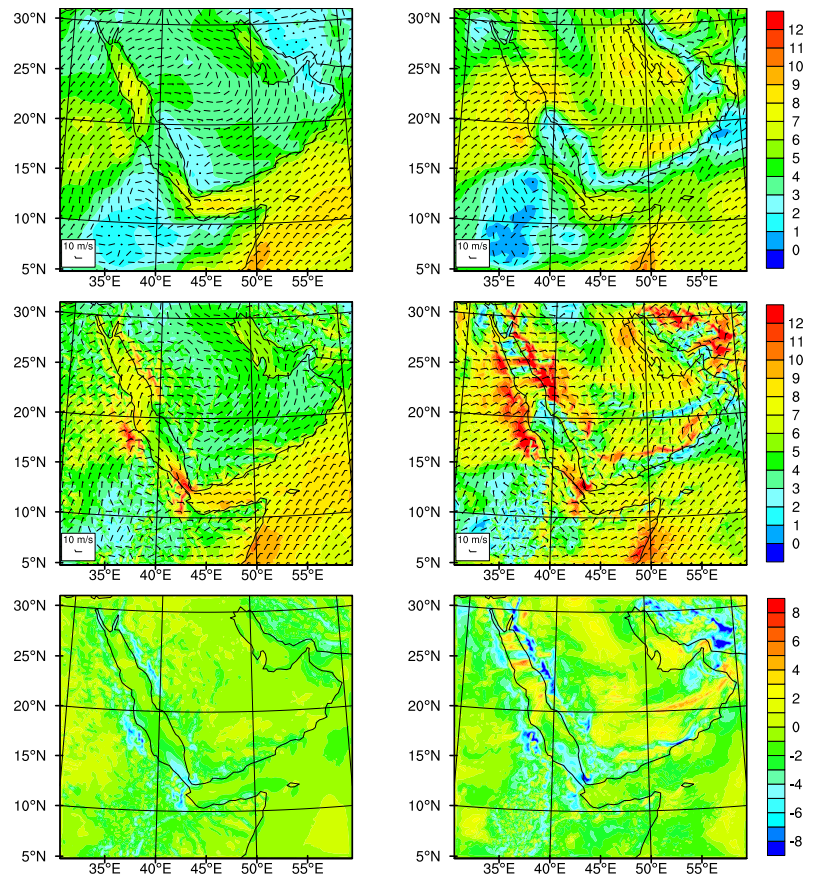

Fig. 2. ERA-Interim 10m-wind fields (upper row), modeled $10 \mathrm{~m}$ wind fields (middle row), the difference between ERA-Interim and modeled $10 \mathrm{~m}$-wind fields (lower row). Instantaneous fields (right column) at 12:00 UTC on 14 January 2009 and the averaged fields (left column) are well correlated with correlation coefficient of 0.62 and 0.82 , respectively.

image (Fig. 1). Similar results are obtained for the other meteorological fields (e.g. T2, not shown).

\subsection{Modeling the distribution of dust}

\subsubsection{Emission rates}

Dust emissions are calculated interactively from Eq. (1) using surface feature data and predictions of surface winds as described by Bagnold et al. (1941). Figure 3 shows the spatial distribution of dust emission fluxes (upper panel) averaged over the simulation period. The emitted total dust amount was $18.3 \mathrm{Tg}$ for the entire domain and simulation period. As to the global impact of this dust outbreak event, it is interesting to compare it with the Pinatubo eruption of 1991 (Stenchikov et al., 1998). Pinatubo injected into the atmosphere $17 \mathrm{Tg}$ of $\mathrm{SO}_{2}$ that has been converted to sulfate aerosols and affected the Earth's climate globally decreasing the global surface air temperature by $0.5 \mathrm{~K}$. Thus one dust outbreak could inject in the atmosphere aerosol mass comparable with the Pinatubo-size effect. Though, stratospheric aerosols have much longer lifetime than the tropospheric dust particles.

The similarity between the spatial distribution of the emissions and the prescribed source function, $S$, as shown in 

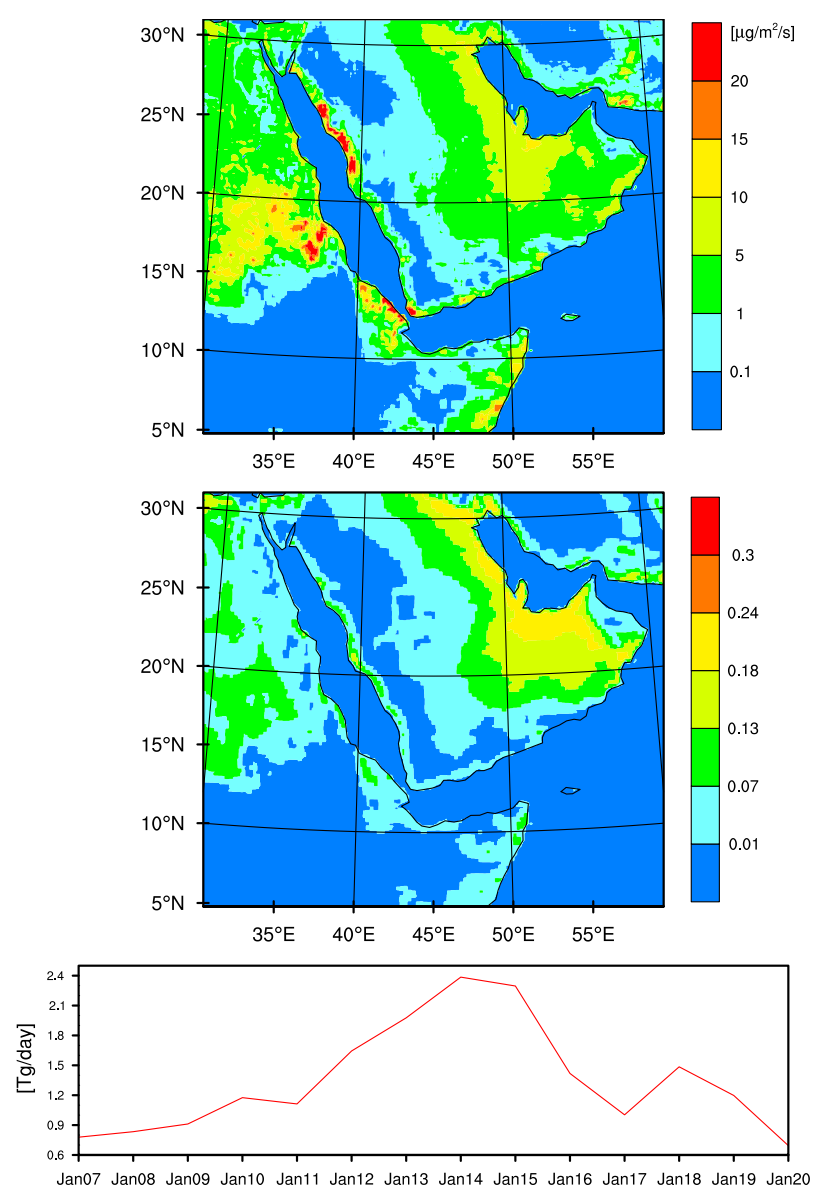

Fig. 3. Averaged for the simulation period of 7-20 January 2009 dust emissions $\left[\mu \mathrm{g} \mathrm{m}^{-2} \mathrm{~s}^{-1}\right]$ (top), source function (middle), and daily dust emissions $\left[\mathrm{Tg} \mathrm{day}^{-1}\right]$ (bottom).

Fig. 3 (middle panel), indicates the dominate role of $S$ in Eq. (1). The most intense dust emissions are simulated to be within the basin of the Arabian Desert, which includes the great An-Nafud Sand Sea (40-45 E; 27-29 ${ }^{\circ}$ N), the Rub Al Khali desert $\left(44-56^{\circ} \mathrm{E} ; 16-23^{\circ} \mathrm{N}\right)$, and the Ad-Dahna desert $\left(45-48^{\circ} \mathrm{E} ; 25-28^{\circ} \mathrm{N}\right)$. It can also be seen that the dust source region between $22^{\circ} \mathrm{N}$ to $25^{\circ} \mathrm{N}$ and about $50 \mathrm{~km}$ wide along the west coast of the Arabian Peninsula could potentially play an important role in the dust outflow from the Arabian Peninsula across the Red Sea. Daily simulated dust emissions over the entire domain are also reported in Fig. 3 (lower panel). The emission scheme (1) captures two major dust events on 14 January and 18 January with maximum daily emissions of $\sim 2.4 \mathrm{Tg}$ and $\sim 1.5 \mathrm{Tg}$, respectively. The dust event on 14 January is more intense and was partially captured by MODIS satellite observations (Fig. 1, left panel) and the event on 18 January was well captured (will be shown in Sect. 4.2) by the Solar Village AERONET site. Interestingly, these values are comparable with those reported by Laurent et al. (2006) on daily dust emissions over the Taklimakan desert area in northwestern China.

\subsubsection{Spatial distributions of dust}

The MADE/SOGRAM aerosol model is based on a modal representation of the aerosol size distribution in which the total mass is divided in three modes: nucleation, accumulation, and coarse. The lognormal distribution is assumed within each mode and it is given by

$n\left(\ln d_{\mathrm{p}}\right)=\frac{N}{\sqrt{2 \pi} \ln \sigma_{\mathrm{g}}} \exp \left\{-\frac{1}{2} \frac{\left(\ln d_{\mathrm{p}}-\ln d_{\mathrm{g}}\right)^{2}}{\ln ^{2} \sigma_{\mathrm{g}}}\right\}$,

where $N$ is the number concentration $\left[\mathrm{m}^{-3}\right], d_{\mathrm{p}}$ is the particle diameter, $d_{\mathrm{g}}$ is the median diameter, and $\sigma_{\mathrm{g}}$ is the standard deviation of the distribution. While the standard deviation values, $\sigma_{\mathrm{g}}$, are prescribed $(1.7,2.0,2.5$ for nucleation, accumulation and coarse modes, respectively), the mean diameter values, $d_{\mathrm{g}}$, are updated from the predicted aerosol mass and number concentrations. The prescribed values for the standard deviation, $\sigma_{\mathrm{g}}$, are close to those obtained for Saharan dust during several aircraft campaigns (Osborne et al., 2008; Weinzierl et al., 2009, 2011). The emitted dust particles are distributed in the accumulation and coarse modes with the mass fraction coefficients equal to $7 \%$ and $93 \%$, respectively. Figure 4 shows the daytime mean spatial distribution of the dust mass concentration in the lower atmosphere $(<1 \mathrm{~km}$ a.g.l. $)$ during the simulation period. The coarse mode is shown in the top panel; the accumulation mode in the middle panel; and the total concentration in the bottom panel. In general, the spatial distribution of the dust mass concentration is consistent with the spatial patterns of dust emissions shown in Fig. 3. While the predictions for the coarse and accumulation modes are similar over the Red Sea, the coarse mode is mostly responsible for the dust loading over the regions with the highest dust concentrations, including the middle part of East North Africa, Rub Al Khali, and eastern coast of the Arabian Peninsula.

Figure 5 shows three vertical cross-sections of the dust concentration averaged over the simulation period and their geographic locations. The dust layer is thick, extensive, and mixed up in a deep boundary layer up to $3-4 \mathrm{~km}$ altitude, which facilitates long-range transport over the entire domain. The dust plume over the Red Sea is formed by two major dust source regions along the east and west coast of the Arabian Peninsula as observed above. The dust plume that is formed over the east coast of the Arabian Peninsula and the Rub Al Khali region moves northwest and is mixed with the dust plume that is formed along the east coast of Red Sea, resulting in marked dust events over the Red Sea. The longitudeheight cross-section of dust at $13^{\circ} \mathrm{N}$ (top left panel) reveals that the dust transport could be largely limited because of the blocking effect of the steep mountains along the coast of Red Sea in this part of the basin. Moving northward, the vertical 

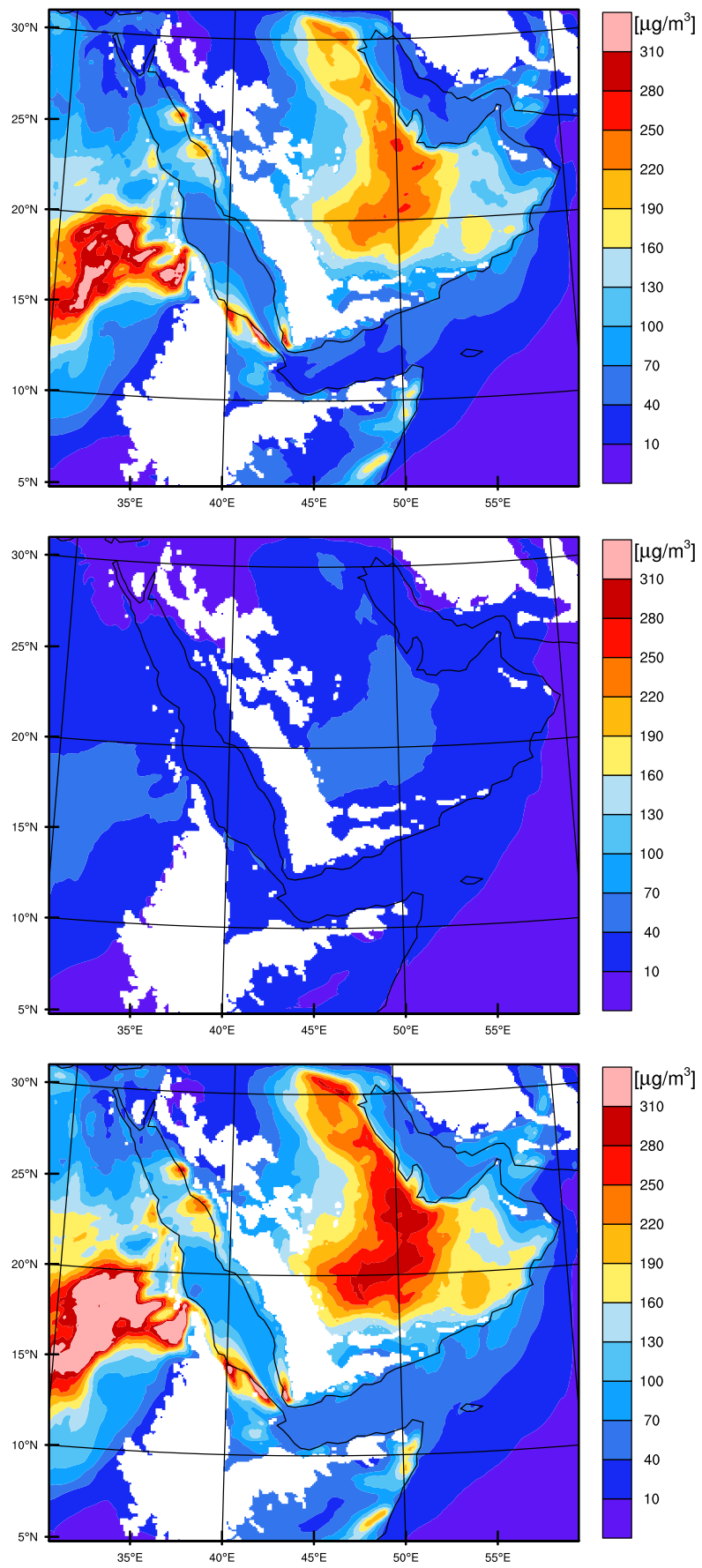

Fig. 4. Daytime (07:00-14:00 UTC) mean spatial distributions of the dust mass concentration $\left[\mu \mathrm{g} \mathrm{m}^{-3}\right]$ in the lower atmosphere averaged over the simulation period: coarse mode (top panel), accumulation mode (middle panel), and total concentrations (bottom panel).

dust cross-section at $23^{\circ} \mathrm{N}$ (top right panel) indicates that the height of the dust plume reaches beyond $3 \mathrm{~km}$ and that the thickness of the dust layer tapers off away from the peninsula due to deposition processes. The last east-west dust crosssection at $27^{\circ} \mathrm{N}$ (bottom left panel) indicates that the dust
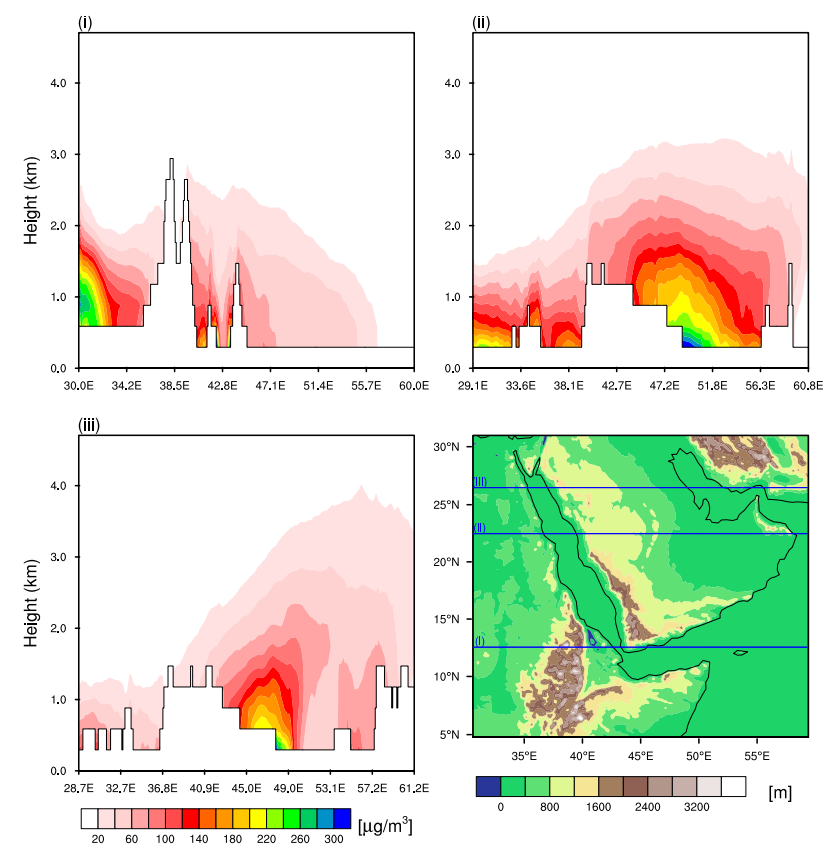

Fig. 5. Three vertical cross-sections of the averaged over the simulation period dust mass concentration field $\left[\mathrm{\mu g} \mathrm{m}^{-3}\right]$ (top left, right, and bottom left panels) and their location on geographical map [m] (bottom right panel).

plume formed over the west coast of the peninsula is the primary contributor to the dust field over the Red Sea. However, dust transport from the peninsula over the Arabian Sea is extensive at that latitude. Similar results were reported by $\mathrm{Pa}-$ payannis et al. (2005) who reported the vertical distributions of Saharan dust aerosols over the northeastern Mediterranean region as observed by two LIDAR systems during a typical dust outbreak in August 2000.

\subsection{The optical properties and heating rates of dust}

A parameterization (Ghan and Zaveri, 2007) of the Mie theory is employed in WRF-Chem to calculate the optical properties of aerosols, such the extinction coefficient, the single scattering albedo, and the asymmetry factor required by the radiative transfer model. The parameterization is modified for the sectional representation of the aerosol size distribution (Fast et al., 2006; Barnard et al., 2010) and is relatively efficient computationally and general enough to account for the variability in aerosol composition, size distribution, and ambient relative humidity, which are difficult to capture using the common method of lookup tables. The effects of water uptake and the internal mixture are treated as a variation of the particle wet diameter $\left(d_{\mathrm{w}}\right)$ and the wet refractive index $\left(n_{\mathrm{W}}\right)$. The wet diameter can be obtained from the dry mode diameter by accounting for the relative humidity and the wet refractive index can be obtained from the composition of the aerosol particles and the complex refractive index of each 

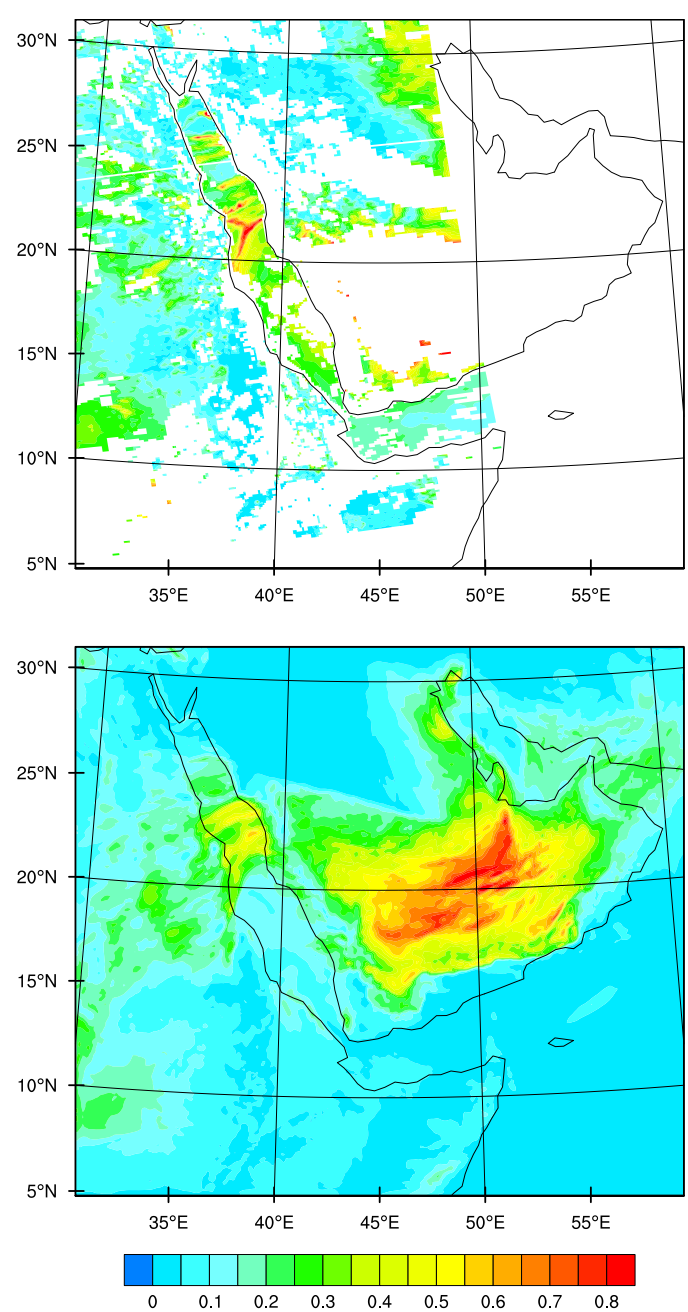

Fig. 6. Simulated AOD (600 nm, bottom panel) at 11:00 UTC on 14 January 2009 and observed AOD (550 nm, upper panel) combined from two MODIS retrievals at 10:00 and 10:55 UTC on 14 Jan 2009. The MODIS AOD is obtained using the standard ocean and "Deep Blue" products.

component. Once $d_{\mathrm{w}}$ and $n_{\mathrm{w}}$ are calculated, an aerosol optical property $(P)$ is parameterized as

$$
P=\exp \left(\sum_{k=0}^{4} A_{k}\left(n_{\mathrm{w}}\right) T_{k}(x)\right),
$$

where

$x=\frac{2 \log \left(d_{\mathrm{w}}\right)-\log \left(d_{\min }\right)-\log \left(d_{\max }\right)}{\log \left(d_{\max }\right)-\log \left(d_{\min }\right)}$,

$T_{k}(x)$ is the Chebyshev polynomial of order $k$, and $A_{k}$ are the Chebyshev coefficients interpolated bilinearly from a table of coefficients. The table of coefficients is calculated by fitting the Chebyshev polynomials to a set of full Mie calculations performed once at the beginning of the simulation. Later, only Eq. (6) is used to calculate the optical properties of the aerosols.
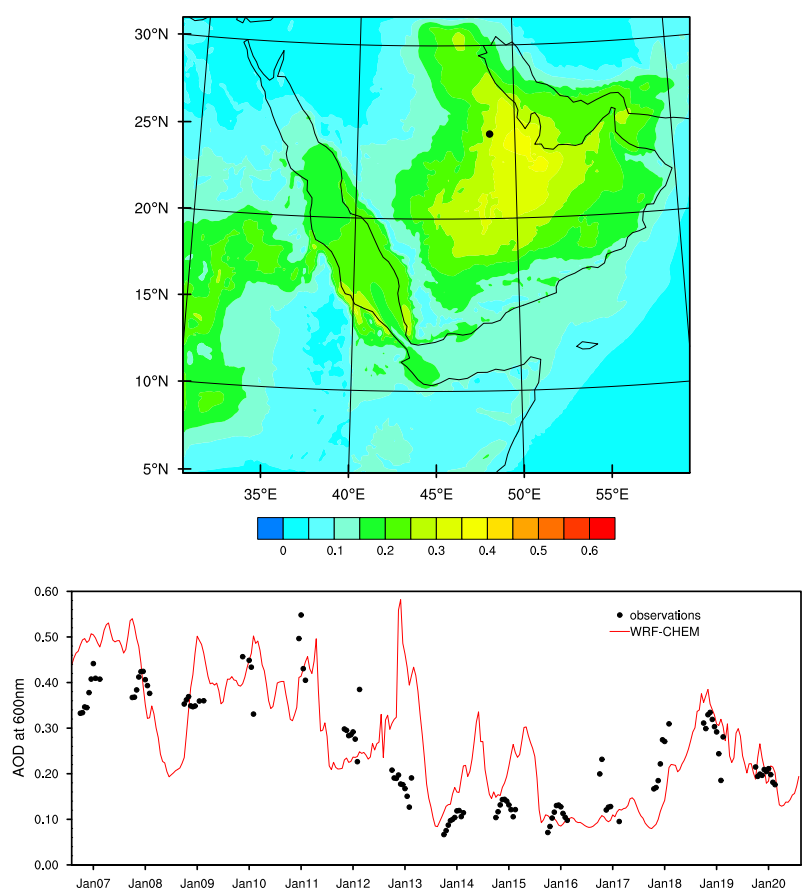

Fig. 7. Mean daytime (08:00-14:00 UTC) spatial distributions of the simulated AOD at $600 \mathrm{~nm}$ averaged over the simulation period (upper panel). The black dot in the upper panel indicates the location of the AERONET Solar Village site. The lower panel shows the time series of the observed and simulated AOD at $600 \mathrm{~nm}$.

\subsubsection{Aerosol Optical Depth (AOD)}

Aqua-MODIS observations have limited special and temporal coverage over the modeled domain. The available observations usually cover different parts of the domain twice per day (day and night). These limitations plus cloudiness make comparisons of the MODIS and simulated data difficult on the time scale of the simulation period (a few weeks). Figure 6 shows the simulated AOD (600 nm) at 11:00 UTC on 14 January 2009, in comparison with two MODIS retrievals $(550 \mathrm{~nm})$ at 10:00 and 10:55 UTC on 14 January 2009, observations taken during the integration period. The MODIS retrievals are a combination of the standard ocean and Deep Blue products. The observed MODIS AOD values compare well to the high optical depth values simulated over the entire domain whenever they are available. Unfortunately, because of clouds and insufficient coverage, very few MODIS observations are available over the Rub $\mathrm{Al}$ Khali area, where the predicted AOD values are the highest at that time.

Figure 7 shows the mean spatial distribution of the simulated AOD at $600 \mathrm{~nm}$ (upper panel) and a comparison between the hourly calculated AOD and the corresponding AERONET values at the Solar Village site during the simulation period (lower panel). Since AERONET does instantaneous measurements during the daytime, the data were averaged to hourly values for comparison with the simulated 
AOD values. The mean values of these time series are consistent since the simulated mean value $(0.25)$ was obtained from a sample when the AERONET measurements were available and the observed AERONET mean value (0.28) was used to tune the dust emissions scheme, i.e., the value of the proportionality constant, $C$. The dust event predicted by WRFChem on 18 January 2009 is verified by the observed AOD measurements at the Solar Village station and generally the two time series correlate well with each other most of the time $($ RMSE $=0.11)$. Our WRF-Chem simulations show that the dust contribution in the total AOD averaged over the simulation period is $88 \%$. The mean spatial distribution of the simulated AOD (upper panel) is consistent with the climatology values and spatial patterns reported by Ginoux et al. (2001) and Prospero et al. (2002) for this region and this time of the year with the highest AOD over the Rub Al Khali region.

\subsubsection{Heating rates of aerosols}

The rate of change of temperature in a layer, known as the aerosol heating rate, depends on the optical properties and vertical distribution of the aerosols. The heating rate may therefore vary significantly from one region to another. Zhao et al. (2011) analyzed the sensitivity of heating rates simulated by WRF-Chem to dust absorption properties by using different values for the imaginary part of the dust refractive index. In this study, the imaginary part of the dust refractive index for solar spectrum is not wavelength-dependent and set to 0.006 (strongly absorbing dust), which gives comparable results with some other studies in terms of the dust radiative forcing at the TOA (e.g. Mallet et al., 2009). This assumption is within the range of uncertainty observed in the AERONET values for the Solar Village site and this particular period of simulation. Uncertainties on the imaginary part of the dust refractive index retrieved from AERONET observations are $50 \%$ as reported by Dubovik et al. (2002). Figure 8 presents the vertical profiles of the dust induced perturbations in solar heating rates averaged during the simulation period at 10:00 UTC over the Solar Village station. It is apparent that the presence of dust in the lower atmosphere leads to a significant increase in the shortwave heating rates. The peak heating rate at 10:00 UTC is found at about $1.2 \mathrm{~km}$ with a mean value of $1.68 \mathrm{~K} \mathrm{day}^{-1}$. Above this altitude, the solar heating rate perturbations gradually decrease to become insignificant at $5 \mathrm{~km}$. In comparison, Zhao et al. (2010) modeled the mean daytime dust heating profiles with maximum rates up of $0.7 \mathrm{~K} \mathrm{day}^{-1}$ in January 2006 at Niamey Airport in Niger, Africa. Liu et al. (2011) reported maximum daily heating rates of $2.74 \mathrm{~K} \mathrm{day}^{-1}$ and $1.91 \mathrm{~K} \mathrm{day}^{-1}$ for two dust events that occurred in southeast China during 14-17 March and 25-26 April 2009. The mean simulated SSA at $600 \mathrm{~nm}$ over the Solar Village was 0.98 , which is slightly higher than the SSA of 0.95 in (Giles et al., 2012) for the same location, and comparable to the value of $0.99 \pm 0.01$ reported by Os-

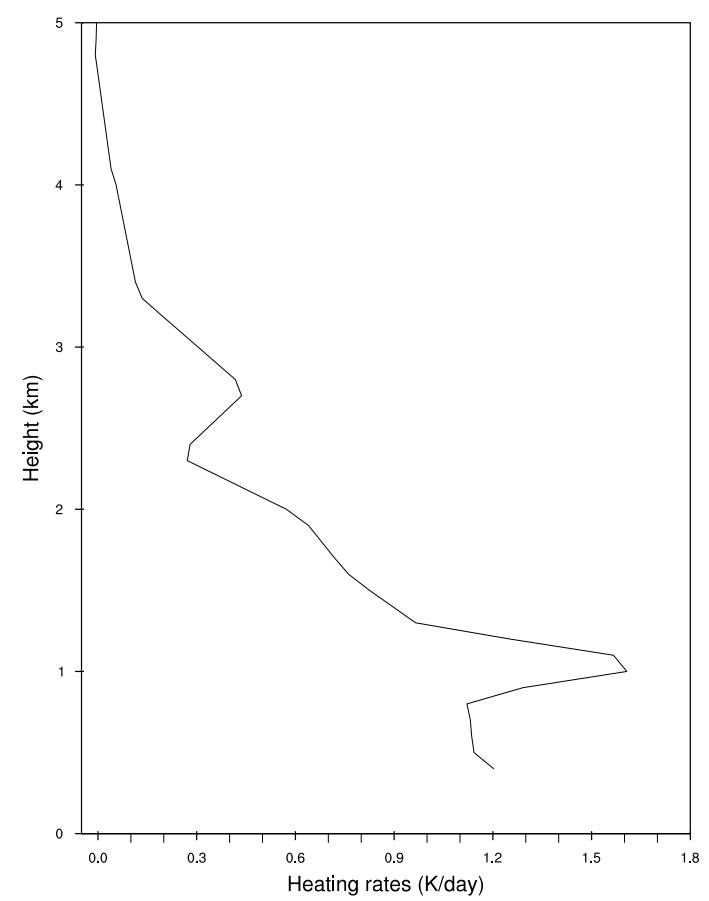

Fig. 8. Dust-induced perturbations of the clear-sky solar heating rates $\left[\mathrm{Kday}^{-1}\right]$ in atmosphere over the AERONET Solar Village site at 10:00 UTC averaged over the simulation period of 7-20 January 2009.

borne et al. (2008) for Saharan dust. The warming effect of the dust layer aloft and cooling at the surface could affect the stability and turbulent mixing of the lower atmosphere and thus the boundary layer properties.

\subsection{Radiative forcing from dust}

\subsubsection{The impact of dust on the radiation budget}

The impact of the radiative forcing of dust on the radiation budget is determined from the difference between the net radiative fluxes obtained in two parallel simulations at the surface (SFC) and the top of the atmosphere (TOA) as follows:

$\Delta F_{\mathrm{SFC}}=F_{\mathrm{SFC}}^{\mathrm{w}}-F_{\mathrm{SFC}}^{\mathrm{o}}$,
$\Delta F_{\mathrm{TOA}}=F_{\mathrm{TOA}}^{\mathrm{w}}-F_{\mathrm{TOA}}^{\mathrm{o}}$

where $F$ is the net radiative flux (either SW or LW), which is the difference between the downward $(F \downarrow)$ and upward ( $F \uparrow$ ) fluxes:

$F=F \downarrow-F \uparrow$,

and "(w)" and "(o)" indicate radiative fluxes with and without aerosol radiative effect, respectively. This convention is used both for longwave (LW) and shortwave (SW) radiation and a negative sign implies an overall cooling effect whereas a positive sign implies an overall heating effect. It should 
also be noted that the downward SW flux is the dominant component in the net flux calculations at the surface and that the upward SW flux is the dominant component at the TOA. We below consider the dust effect for clear sky conditions and call it radiative forcing, although, strictly speaking, it includes atmospheric and surface temperature responses.

Figure 9 shows the spatial distribution of the clear sky daily averaged SW (upper row), LW (middle row), and total (lower row) radiative effects from dust at the surface (left column) and at the TOA (right column). As shown in the figure, SW radiative forcing at the surface is negative almost everywhere with a domain averaged value of $-6.0 \mathrm{~W} \mathrm{~m}^{-2}$ and a maximum of $-19.2 \mathrm{~W} \mathrm{~m}^{-2}$. Comparable values for SW radiative forcing at the surface were found by Han et al. (2011). In their work, the reported monthly averaged values, obtained with the RAMS-CMAQ model, ranged from -12 to $-8 \mathrm{~W} \mathrm{~m}^{-2}$ for East Asia. McFarlane et al. (2009) reported 24-h averaged SW instantaneous surface aerosol radiative forcing of $-21.1 \pm 14.3 \mathrm{~W} \mathrm{~m}^{-2}$ at Niamey, Niger, during 2006. Finally, Satheesh et al. (2006) estimated the daily averaged surface radiative forcing over the Arabian Sea to be from -16.2 to $-5.5 \mathrm{~W} \mathrm{~m}^{-2}$ during the winter monsoon season. The LW radiative forcing at the surface (middle row) has the opposite sign compared to SW forcing; i.e., the elevated dust layer increases LW radiation at the surface, causing overall warming with a domain averaged value of $1.7 \mathrm{~W} \mathrm{~m}^{-2}$ and a maximum of $6.1 \mathrm{~W} \mathrm{~m}^{-2}$, which are consistent with the values of $0.9-1.4 \mathrm{~W} \mathrm{~m}^{-2}$ (depending on the altitude of the dust layer) reported by Liao and Seinfeld (1998). However, the net radiative effect (lower panel) is dominated by the SW radiative forcing and overall (land + ocean) is cooling with a domain-averaged value of $-4.3 \mathrm{~W} \mathrm{~m}^{-2}$ and a maximum of $-16 \mathrm{Wm}^{-2}$. It should be highlighted here that the instantaneous surface forcing of dust (not shown) can be considerably larger than the daily averaged one. For example, the simulated instantaneous solar radiative forcing at the surface reached up to $-205 \mathrm{~W} \mathrm{~m}^{-2}$ over the Arabian Sea at noon on 14 January 2009 and had a regional mean value of $-14.1 \mathrm{~W} \mathrm{~m}^{-2}$. These results are comparable with results obtained in previous studies: Slingo et al. (2006) reported that the incoming solar fluxes at the surface dropped by $250 \mathrm{~W} \mathrm{~m}^{-2}$ during a major Saharan dust storm; Mallet et al. (2009) simulated a remarkable instantaneous (at midday) decrease in the surface SW radiation, with a regional mean of $-137 \mathrm{~W} \mathrm{~m}^{-2}$ and a maximum of $-400 \mathrm{~W} \mathrm{~m}^{-2}$, over West Africa during March 2006.

The right column of Fig. 9 displays the spatial distribution of the simulated clear sky daily averaged SW (upper row), LW (middle row), and total (lower row) radiative effect of dust at TOA. The SW radiative forcing (upper panel) is always negative over the ocean and could be either positive or negative over the land with a domain-averaged value of $-2.3 \mathrm{~W} \mathrm{~m}^{-2}$ and a maximum of $-17.8 \mathrm{~W} \mathrm{~m}^{-2}$. Over oceanic regions, the SW cooling effect at TOA is stronger due to the smaller surface albedo, where the scattering effects dominate
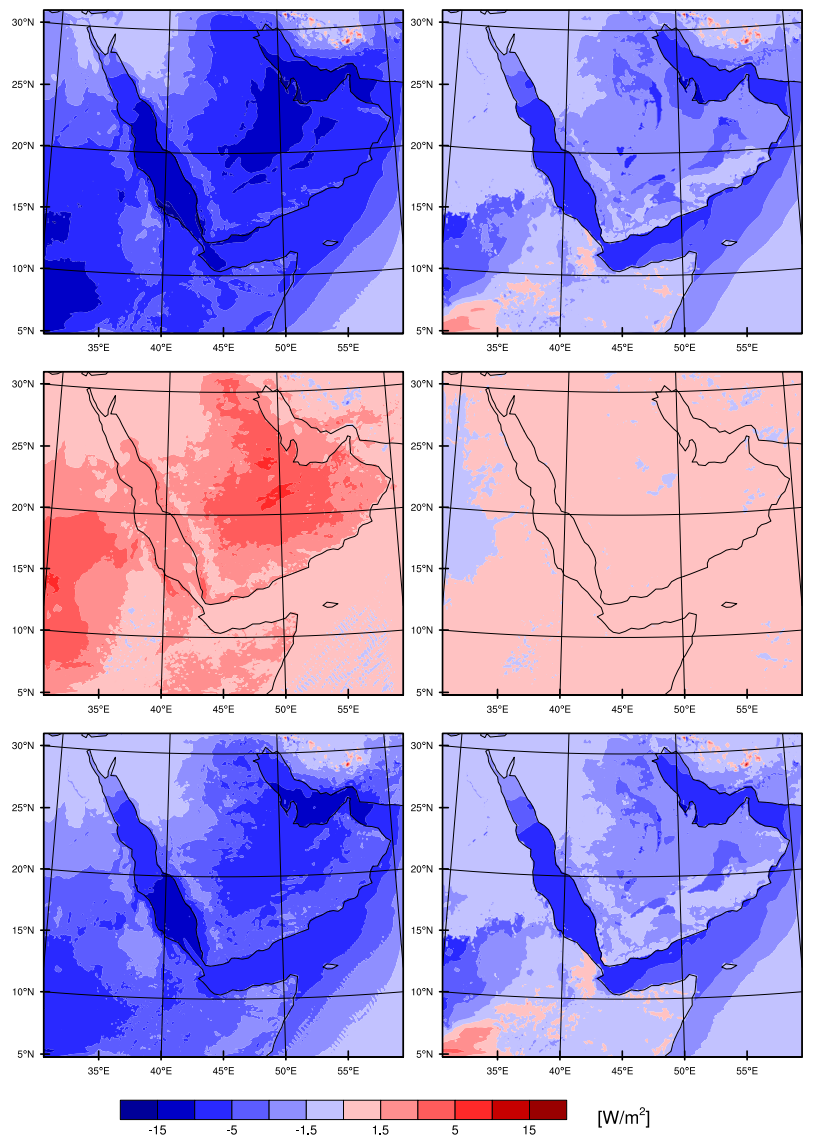

Fig. 9. Clear sky daily averaged SW (upper row), LW (middle row), and $\mathrm{SW}+\mathrm{LW}$ (lower row) radiative forcing of dust $\left[\mathrm{W} \mathrm{m}^{-2}\right]$ at the surface (left column) and at TOA (right column).

and more SW energy is reflected back to space. Over bright surfaces with wide ranges of surface albedo and dust type, scattering (cooling) and absorbing (warming) effects compensate each other, resulting in a smaller SW radiative forcing at TOA. Sensitivity tests reveal that the sign and magnitude of SW instantaneous forcing over the land strongly depend on the SW absorptivity of the dust. Using a value of 0.003 (moderate absorbing dust) for the imaginary part of the refractive index creates negative SW forcing at TOA over the entire domain including the Rub Al Khali region icreasing the overall domain-averaged TOA cooling by a factor of 2 , while a value of 0.006 creates positive instantaneous forcing over a large part of the peninsula (not shown). The LW forcing is small and mostly positive with daily mean values between -2.7 and $1.8 \mathrm{~W} \mathrm{~m}^{-2}$ (mean of $0.2 \mathrm{~W} \mathrm{~m}^{-2}$ ). The total daily averaged TOA radiative forcing (lower panel) is generally negative with a domain-averaged value of $-2.1 \mathrm{~W} \mathrm{~m}^{-2}$. Therefore, within the atmosphere, the radiative effect of dust $\left(\Delta F_{\mathrm{ATM}}=\Delta F_{\mathrm{TOA}}-\Delta F_{\mathrm{SFC}}\right)$ is $2.3 \mathrm{~W} \mathrm{~m}^{-2}$, indicating a heating effect from dust aerosols caused mostly by absorption of solar radiation. For comparison, Ge et 
al. (2010) calculated a daily averaged SW radiative forcing of $0.52 \pm 1.69 \mathrm{~W} \mathrm{~m}^{-2}$ at TOA for Zhangye, which is located in a semi-arid area in northwest China, during the period of late April to mid-June in 2008. Satheesh et al. (2006) simulated the daily averaged SW radiative forcing over the Arabian Sea as ranging from -7.3 to $-6.1 \mathrm{~W} \mathrm{~m}^{-2}$, with the $\mathrm{LW}$ forcing from 0.8 to $1.2 \mathrm{~W} \mathrm{~m}^{-2}$, and the total forcing from -6.1 to $-5.2 \mathrm{~W} \mathrm{~m}^{-2}$ at TOA, during the winter monsoon season for $8 \mathrm{yr}$ from 1995 to 2002. Mallet et al. (2009) simulated the instantaneous net cooling effect at TOA with regional mean of $-12.0 \mathrm{~W} \mathrm{~m}^{-2}$ over West Africa during March 2006.

\subsubsection{Impact on surface energy budget}

WRF-Chem allows online interaction of the simulated dust field with the SW and LW radiation and consequently with the model dynamics. In this section, we investigate the responses of the surface latent heat fluxes (LH), the sensible heat flux (SH), and the two meter temperature (T2) to the radiative forcing of dust. Figure 10 shows the spatial distribution of instantaneous (at 12:00 UTC) LH (upper panel), SH (middle panel), and T2 (lower panel) atmospheric responses averaged over the simulation period. The maximum response of the latent heat flux occurs at around 12:00 UTC, about 2$3 \mathrm{~h}$ after the maximum dust radiative effect at 10:00 UTC. Simulations indicate that the negative dust surface forcing causes a small overall decrease in the domain-averaged $\mathrm{LH}$ of $-0.2 \mathrm{~W} \mathrm{~m}^{-2}$ (<1\%), SH of $-6.1 \mathrm{~W} \mathrm{~m}^{-2}(<5 \%)$, and $\mathrm{T} 2$ of -0.1 . However, as observed in the figure, the variations in $\mathrm{LH}, \mathrm{SH}$, and $\mathrm{T} 2$ can be locally significant up to $-45.2 \mathrm{~W} \mathrm{~m}^{-2},-45.6 \mathrm{~W} \mathrm{~m}^{-2}$, and $-0.7 \mathrm{~K}$, respectively. In general, sensible heat fluxes are strongly reduced over land surfaces (mostly source regions) caused by a reduction in the temperature over the land, but with relatively small changes over the ocean, which is because the SST is prescribed in both simulations with and without dust radiative feedback. For the same reason the air temperature over the Red Sea does not fully respond to the dust radiative forcing. The slight increase of T2 over the Red Sea could be caused by the increase of the downward thermal radiation fluxes from the lower troposphere heated by absorption of solar radiation by dust particles. However, it should be noted that the short-term dust impact on SST should be small because of the high heat capacity of the ocean (Zhao et al., 2011).

For comparison, Mallet et al. (2009) reported a surface temperature decrease of about $-0.68 \mathrm{~K}$ (at noon) averaged over the $9-17^{\circ} \mathrm{N}, 10^{\circ} \mathrm{W}-20^{\circ} \mathrm{E}$ region, for 9-12 March 2006 and intense decreases of the sensible heat flux with a maximum of $200 \mathrm{~W} \mathrm{~m}^{-2}$ corresponding to higher dust AOD. Miller et al. (2004) reported a global and annual averaged decrease of $-1.13 \mathrm{~W} \mathrm{~m}^{-2}$ in $\mathrm{LH}$ and $-0.47 \mathrm{~W} \mathrm{~m}^{-2}$ in $\mathrm{SH}$ for AGCM experiments. Additionally, they also pointed out that despite its dominant role on the global scale as a compensating mechanism for the dust radiative forcing at the surface, LH may increase locally over arid regions that are sources of
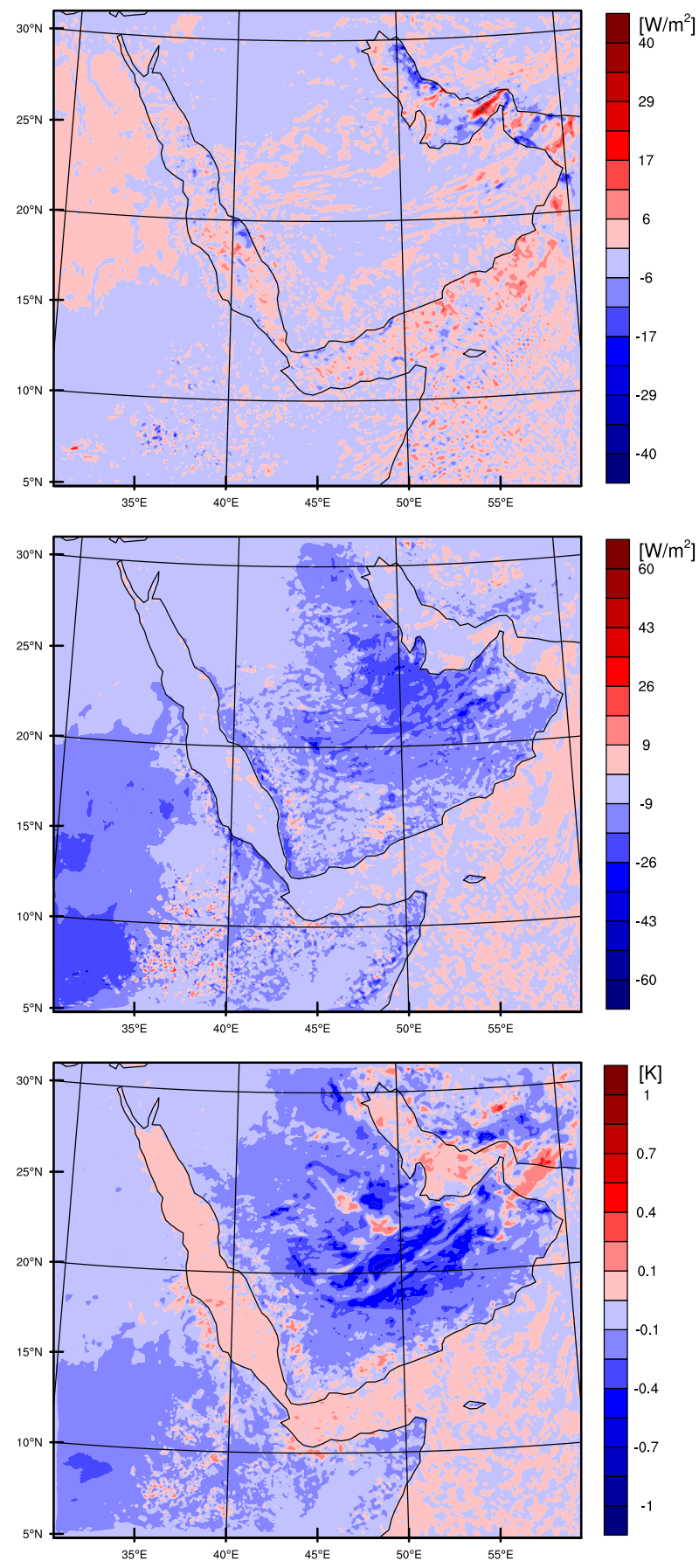

Fig. 10. Spatial distribution of dust-induced perturbations of instantaneous (at 12:00 UTC) latent heat flux [ $\left.\mathrm{W} \mathrm{m}^{-2}\right]$ (upper panel), sensible heat flux $\left[\mathrm{W} \mathrm{m}^{-2}\right]$ (middle panel), and air temperature at twometer altitude $[\mathrm{K}]$ (lower panel) averaged over the simulation period of 7-20 January 2009.

dust. This effect is quite consistent with the results shown in the Fig. 10. 


\subsection{Dust deposition}

Dust particles can be removed from the atmosphere by dry and/or wet deposition processes. During the simulation period, there was no precipitation over the region. Dry deposition was therefore the dominant removal process in this study. The dry deposition flux of dust $\left(F_{\mathrm{d}}\right)$ is calculated by multiplying the dust concentration $(C)$ in the lowest model layer by the deposition velocity $\left(V_{\mathrm{d}}\right)$ for both accumulation and coarse modes as follows:

$F_{\mathrm{d}}=C_{\mathrm{a}} \times V_{\mathrm{da}}+C_{\mathrm{c}} \times V_{\mathrm{dc}}$,

where the subscripts (a) and (c) refer to the accumulation and coarse modes, respectively. Dry deposition velocities in WRF-Chem are parameterized based on Binkowski and Shankar (1995). This parameterization takes into account deposition processes such as the turbulent transfer of aerosol particles to the surface, gravitational settling, diffusion, impaction, and interception. Figure 11 (upper panel) shows the spatial distribution of dust deposition rates averaged over the simulation period. The highest deposition rates are found over the source regions with the maximum greater than $450 \mathrm{~g} \mathrm{~m}^{-2} \mathrm{yr}^{-1}$ at a few isolated locations and a domainaveraged value of $43.3 \mathrm{~g} \mathrm{~m}^{-2} \mathrm{yr}^{-1}$. The total deposition for the entire domain and simulation period is $14.3 \mathrm{Tg}$, less than the earlier reported (Sect. 4.1.1) emitted total dust amount of 18.3 Tg. Simulated daily depositions are shown in the lower panel of Fig. 11. Similar to the daily emissions (Fig. 3, lower panel), the dust deposition time series has two peaks as well although there is a lag time of $24 \mathrm{~h}$ between the peaks of deposition and emission. For comparison, Zhang et al. (1993) estimated dust dry deposition rates over Huanghai, China (Yellow sea) ranging from $7 \mathrm{~g} \mathrm{~m}^{-2} \mathrm{yr}^{-1}$ to $42 \mathrm{~g} \mathrm{~m}^{-2} \mathrm{yr}^{-1}$ in the winter. Another detailed study estimated that the deposition rates over Chinese deserts ranged from $14 \mathrm{~g} \mathrm{~m}^{-2} \mathrm{yr}^{-1}$ to $2100 \mathrm{~g} \mathrm{~m}^{-2} \mathrm{yr}^{-1}$ (Zhang et al., 1997). Prospero (1996) modeled dust deposition rates for the Mediterranean sea to be 3-14 $\mathrm{g} \mathrm{m}^{-2} \mathrm{yr}^{-1}$, which were comparable to rates obtained from direct measurements. Finally, global dust deposition fluxes over the ocean calculated by Duce et al. (1991) were $1 \mathrm{~g} \mathrm{~m}^{-2} \mathrm{yr}^{-1}$ and $1.5 \mathrm{~g} \mathrm{~m}^{-2} \mathrm{yr}^{-1}$ for dry and wet deposition, respectively, and $2.5 \mathrm{~g} \mathrm{~m}^{-2} \mathrm{yr}^{-1}$ total.

\subsection{The impact of dust on the Red Sea}

The dust outbreak on 14 January 2009 considered in this study provides a good opportunity to evaluate the effect of dust plumes on the Red Sea. The direct effect of cross-sea continental air-mass transport, associated with the coastal terrain gaps (e.g., Tokar Gap), on surface currents and airsea interactions was discussed by Jaing et al. (2009). They mentioned that such episodes are frequent especially in the winter. However, they did not account for dust transport and its radiative effect. Here, we fully consider the effect of the simulated aerosol plume on SW and LW radiation trans-
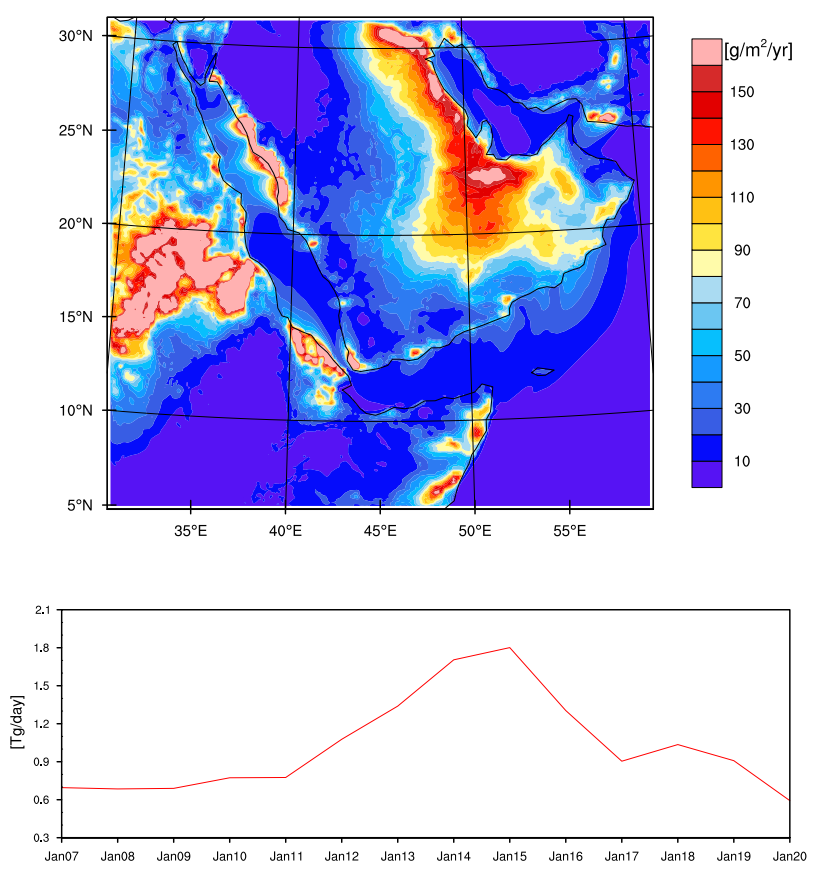

Fig. 11. The mean spatial distribution of the dust deposition rates $\left[\mathrm{g} \mathrm{m}^{-2} \mathrm{yr}^{-1}\right]$ (upper panel) and a time series of the daily dust deposition $\left[\mathrm{Tg} \mathrm{day}^{-1}\right]$ in the study region (lower panel) during the period of simulations of 7-20 January, 2009.

port. We also calculate the amount of dust deposited into the sea during the simulation period. Because there is little river discharge with associated chemical and nutrient inflow in the study area, the atmospheric deposition of aerosols and gaseous chemicals to the Red Sea is extremely important to maintaining nutrient and chemical balances.

The right column in Fig. 9 shows that the averaged aerosol radiative effect at TOA is significantly stronger over the Red Sea than over the surrounding desert areas. The aerosols cool the atmospheric column over the Red Sea by up to $20 \mathrm{~W} \mathrm{~m}^{-2}$. This is because the sea has a lower albedo than the desert and because a reflecting aerosol layer has a relatively stronger effect over the dark sea surface. Figure 12 shows the instantaneous distribution of the aerosol loading and associated anomaly of the net radiative solar flux at the surface at 11:00 UTC on 14 January 2009. Just under the aerosol plume, the solar radiance decreased by almost $100 \mathrm{~W} \mathrm{~m}^{-2}$. This is a reduction of the surface energy balance by about a quarter of the incoming solar flux. Such a cooling should have a profound effect on the sea surface temperature in the Red Sea. The Red Sea has a long-term history of temperature variations. Recently, since the 1990s, an abrupt warming trend is observed (Raitsos et al., 2011). A complete understanding of the Red Sea's evolution and variability is impossible without a detailed quantification of the radiative effects of aerosols. 

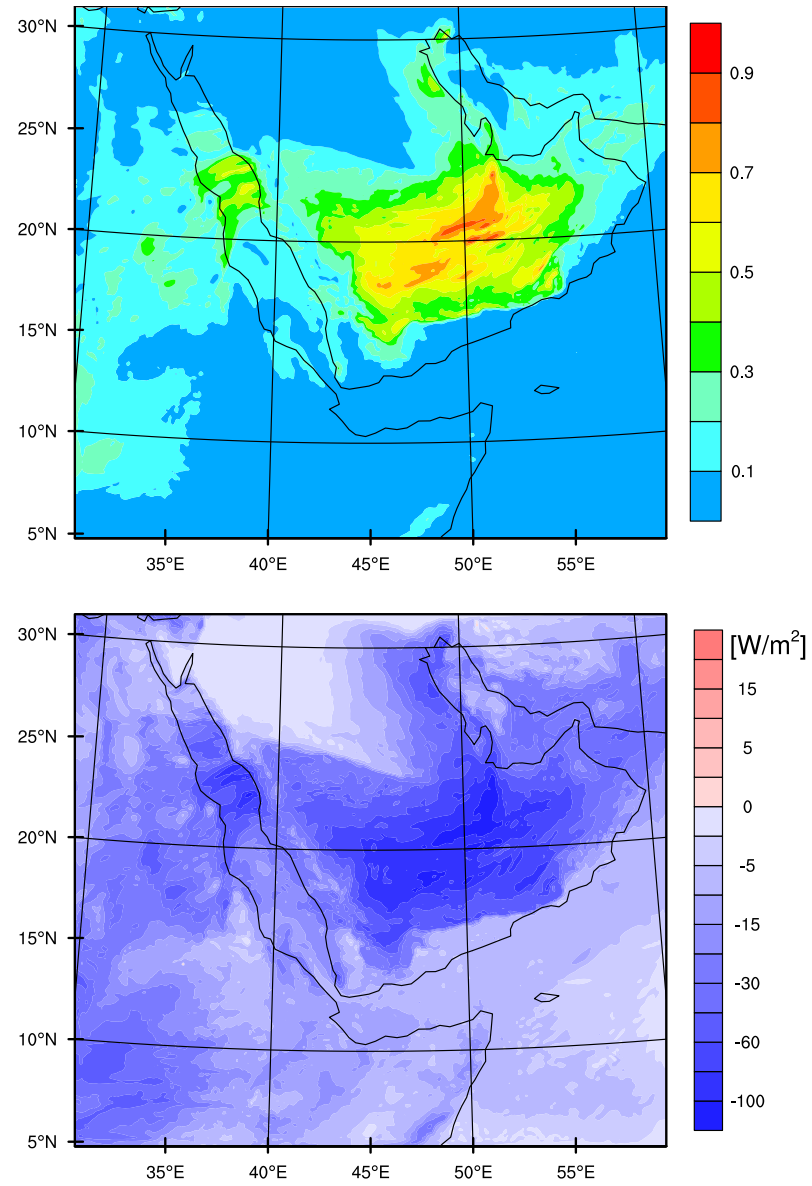

Fig. 12. The spatial distribution of AOD (top panel) and SW radiative forcing $\left[\mathrm{W} \mathrm{m}^{-2}\right.$ ] (bottom panel) at 11:00 UTC on 14 January 2009.

It is well known that the Red Sea is extremely oligotrophic in its central deep areas especially in the North, far from the inflow of nutrient-rich waters from the Indian Ocean through the Bab-el-Mandeb Strait (Acker et al., 2008; Weikert, 1987). The satellite observations show that the chlorophyll concentration in the northern-central part of the Red Sea is about one order of magnitude lower than in the southern part. The delivery of nutrients through atmospheric pathways is therefore especially important to the ecosystems in this part of the Red Sea. Figure 13 shows how the aerosol effective radius changes in the low-level plume moving to the west over the Red Sea in the cross section (ii) shown in Fig. 4. Because of the predominant deposition of coarse particles the effective radius decreases from $6.48 \mu \mathrm{m}$ to $5.91 \mu \mathrm{m}$. During the dust outbreak episode considered in this paper, the total deposition of aerosols to the Red Sea reached $0.65 \mathrm{Tg}$. To quantify annual average nutrient delivery by atmospheric deposition, we plan in future to run multi-season calculations and produce multi-season and multi-year statistics of nutrient deposition to the Red Sea.

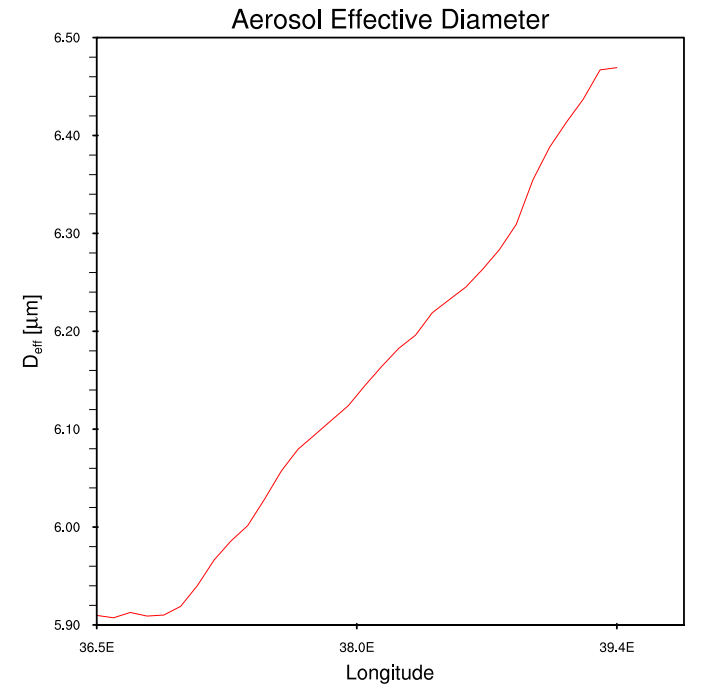

Fig. 13. Aerosol effective diameter $[\mu \mathrm{m}]$ in the lowest model layer along the cross section (ii) in Fig. 4 over the Red Sea averaged over the simulation period. The dust plume moves from East to West and the effective diameter decreases because of the predominant deposition of large particles.

\section{Summary and conclusion}

We used the WRF-Chem model to investigate a typical dust event over the Arabian Peninsula during January 2009. The model simulated intense dust emissions over the basin of the Arabian Desert with the total amount of $18.3 \mathrm{Tg}$ for the entire dust outburst period of 14 days and two daily maximums of $\sim 2.4 \mathrm{Tg}$ and $\sim 1.5 \mathrm{Tg}$, which corresponded to two periods with the highest AOD captured by AERONET and MODIS instruments. The predicted dust plume was thick, extensive, and mixed up in a deep boundary layer of 3-4 km height. In general, dust spatial distributions were consistent with the spatial patterns of dust emissions.

MODIS-Aqua and Solar Village AERONET measurements of AOD and SSA have been used to evaluate the spatial distribution and optical thickness of the aerosol layer calculated by WRF-Chem. The observed MODIS AOD values compared well with the high optical depth values simulated over the entire domain when available. However, because of clouds and the poor spatial and temporal satellite coverage (twice per day) of the domain, further comparisons were difficult on time scale of the simulation period. On the other hand, simulated and observed AERONET hourly measurements of AOD at $600 \mathrm{~nm}$ were similar on most days during the period with average values of 0.28 and 0.25 , respectively. The maximum of the simulated mean dust heating rates at a mean SSA $(600 \mathrm{~nm})$ value of 0.98 over the Solar Village reached $1.68 \mathrm{~K} \mathrm{day}^{-1}$ at a height of $1.2 \mathrm{~km}$. Above this altitude, the heating rate perturbations gradually decreased to become insignificant at $5 \mathrm{~km}$. In general, for accurate assessments of the predicted optical properties of aerosols over the 
modeled region, more observations would be required along with a better understanding of dust phenomena as a whole.

Our results clearly indicate that the presence of dust particles in the atmosphere causes a significant reduction in solar radiation reaching the surface with an instantaneous (daily) regional mean value of $-14.1 \mathrm{~W} \mathrm{~m}^{-2}\left(-6.0 \mathrm{~W} \mathrm{~m}^{-2}\right)$ and a maximum of $-205 \mathrm{~W} \mathrm{~m}^{-2}\left(-19 \mathrm{~W} \mathrm{~m}^{-2}\right)$. The simulated net radiative effect at the top of the atmosphere (TOA) was small with a daily domain-averaged value of $-2.1 \mathrm{~W} \mathrm{~m}^{-2}$, indicating cooling of the earth-atmosphere system. The longwave radiative forcing of dust at the bottom of the atmosphere was positive and small with a domain averaged value of $1.7 \mathrm{~W} \mathrm{~m}^{-2}$, which did not change the overall cooling effect on the surface. At TOA, the daily radiative forcing of dust in general is much smaller than that on the surface. The $\mathrm{LW}$ forcing at TOA is mostly positive with a regional mean value of $0.2 \mathrm{~W} \mathrm{~m}^{-2}$ and ranging from -2.7 to $1.8 \mathrm{~W} \mathrm{~m}^{-2}$. The SW forcing at TOA is always negative over the ocean and could be either positive or negative over the land with a domain-averaged value of $-2.3 \mathrm{~W} \mathrm{~m}^{-2}$. However, the sensitivity test indicates that the sign and magnitude of the TOA SW instantaneous forcing over bright surfaces strongly depend on the solar absorptivity of the dust. Using a value of 0.003 (half value of what was used in the main experiments) for the imaginary part of the refractive index creates negative SW forcing over the entire Arabian peninsula including the Rub Al Khali region. The domain-averaged instantaneous radiative forcing within the atmosphere

is $2.3 \mathrm{~W} \mathrm{~m}^{-2}$, indicating an atmospheric heating effect of dust aerosols caused mostly by absorption of solar radiation.

WRF-Chem allows online interaction of the simulated dust field with the SW and LW radiation and consequently with the model's dynamics. Simulations indicate that the negative surface forcing causes a small overall decrease of the $\mathrm{LH}$ of $-0.2 \mathrm{~W} \mathrm{~m}^{-2}(<1 \%)$, SH of $-6.1 \mathrm{~W} \mathrm{~m}^{-2}$ $(<5 \%)$, and $\mathrm{T} 2$ of -0.1 . However, the variations in $\mathrm{LH}, \mathrm{SH}$, and $\mathrm{T} 2$ can be locally significant up to $-45.2 \mathrm{~W} \mathrm{~m}^{-2},-45.6$ $\mathrm{W} \mathrm{m}^{-2}$, and $-0.7 \mathrm{~K}$, respectively. Additionally, the model also calculates dust deposition rates with a domain-averaged value of $43.3 \mathrm{~g} \mathrm{~m}^{-2} \mathrm{yr}^{-1}$ and the calculated total deposition for the entire domain and simulation period is $14.3 \mathrm{Tg}$.

Dust plumes produce a profound effect on the thermal and chemical balances of the Red Sea by delivering nutrients through dust deposition, reducing solar heating, and affecting air circulation over the sea. Reducing dust transport might significantly damage the ecosystem of the Red Sea and cause overheating of the sea surface. A detailed analysis of dust generation and its spatial and temporal variability is extremely important for better understanding of the climate, ecological history and future evolution of the Red Sea.
Acknowledgements. Stoitchko Kalenderski was partially supported by the King Abdullah University of Science and Technology Academic Excellence Alliance grant "Dust Storms and Climate Change". C. Zhao was partially supported by the Earth System Modeling Program of the US Department of Energy in scope of the project "Investigations on the Magnitude and Probabilities of Abrupt Climate Transitions". We thank Martin Dameris for the editorial guidance. The insightful comments offered by Sebastian Otto and both anonymous referees are highly appreciated.

Edited by: M. Dameris

\section{References}

Acker, J., Leptoukh, G., Shen, S., Zhu, T., and Kempler, S.: Remotely-sensed chlorophyll a observations of the northern Red Sea indicate seasonal variability and influence of coastal reefs, J. Mar. Sys., 69, 191-204, 2008.

Ackermann, F. A. and Chung, H.: Radiative effects of airborne dust and regional energy budget at the top of the atmosphere, J. Appl. Meteor., 31, 223-236, 1992.

Ackermann, I. J., Hass, H., Memmesheimer, M., Ebel, A., Binkowski, F. S., and Shankar, U.: Modal aerosol dynamics model for Europe: Development and first applications, Atmos. Environ., 32, 2981-2999, 1998.

Avila, A., Queralt-Mitjans, I., and Alarcon, M.: Mineralogical composition of African dust delivered by red rains over northeastern Spain, J. Geophys. Res., 102, 21977-21996, 1997.

Bagnold, R. A.: The physics of Blown sand and Desert Dunes, Methuen, New York, 10, 265 pp., 1941.

Barnard, J. C., Fast, J. D., Paredes-Miranda, G., Arnott, W. P., and Laskin, A.: Technical Note: Evaluation of the WRF-Chem "Aerosol Chemical to Aerosol Optical Properties" Module using data from the MILAGRO campaign, Atmos. Chem. Phys., 10, 7325-7340, doi:10.5194/acp-10-7325-2010, 2010.

Binkowski, F. and Shankar, U.: The Regional Particulate Matter Model. 1. Model description and preliminary results, J. Geophys. Res., 100, 148-227, doi:10.1029/95JD02093, 1995.

Haywood, J. and Boucher, O.: Estimates of the direct and indirect radiative forcing due to tropospheric aerosols: a review, Reviews of Geophysics, 38, 513-543, 2000.

Hsu, N. C., Tsay, S. C., King, M. D., and Herman, J. R.: Aerosol properties over bright-reflecting source regions, IEEE Trans. Geosci. Remote Sens., 42, 557-569, doi:10.1109/TGRS.2004.824067, 2004.

Huebert, B. J., Russell, B. T., Shi, P. B., Kim, G., Kawamura, Y. J., Carmichael, K., and Nakajima, G.: An overviewof ACEAsia: strategies for quantifying the relationships between Asian aerosols and their climatic impacts, J. Geophys. Res., 108, 8633 , doi:10.1029/2003JD003550, 2003.

Chen, F. and Dudhia, J.: Coupling an advanced landsurface/hydrology model with the Penn State/ NCAR MM5 modeling system. Part I: Model description and implementation, Mon. Weather Rev., 129, 569-585, 2001.

Dentener, F. J., Carmichael, G. R. , Zhang, Y., Lelieveld, J., and Crutzen, P. J.: Role of mineral aerosol as a reactive surface in the global troposphere, J. Geophys. Res, 101, 22869-22889, 1996.

Dubovik, O. and King, M. D.: A flexible inversion algorithm for retrieval of aerosol optical properties from sun and sky radiance 
measurements, J. Geophys. Res., 105, 20673-20696, 2000.

Dubovik, O., Smirnov, A., Holben, B. N., King, M. D., Kaufman, Y. J., Eck, T. F., and Slutsker, I.: Accuracy assessments of aerosol optical properties retrieved from Aerosol Robotic Network (AERONET) Sun and sky radiance measurements, J. Geophys. Res., 105, 9791-9806, 2000.

Dubovik, O., Holben, B., Eck, T., Smirnov, A., Kaufman, Y., King, M., Tanré, D., and Slutsker, I.: Variability of absorption and optical properties of key aerosol types observed in world-wide locations, J. Atmos. Sci., 59, 590-608, 2002.

Duce, R. A., Liss, P. S., Merrill, J. T., Atlas, E. L., Buat-Menard, P., Hicks, B. B., Miller, J. M., Prospero, J. M., Arimoto, R., Church, T. M., Ellis, W., Galloway, J. N., Hansen, L., Jickells, T. D., Knap, A. H., Reinhardt, K. H., Schneider, B., Soudine, A., Tokos, J. J., Tsunogai, S., Wollast, R., and Zhou, M.: The atmospheric input of trace species to the world ocean, Global Biogeochem. Cy., 5, 193-259, 1991.

Fast, J. D, Gustafson Jr.,W. I., Easter, R. C., Zaveri, R. A., Barnard, J. C., Chapman, E. G., and Grell, G. A.: Evolution of ozone, particulates, and aerosol direct forcing in an urban area using a new fully-coupled meteorology, chemistry, and aerosol model, J. Geophys. Res., 111, D21305, doi:10.1029/2005JD006721, 2006.

Fast, J., Aiken, A. C., Allan, J., Alexander, L., Campos, T., Canagaratna, M. R., Chapman, E., DeCarlo, P. F., de Foy, B., Gaffney, J., de Gouw, J., Doran, J. C., Emmons, L., Hodzic, A., Herndon, S. C., Huey, G., Jayne, J. T., Jimenez, J. L., Kleinman, L., Kuster, W., Marley, N., Russell, L., Ochoa, C., Onasch, T. B., Pekour, M., Song, C., Ulbrich, I. M., Warneke, C., Welsh-Bon, D., Wiedinmyer, C., Worsnop, D. R., Yu, X.-Y., and Zaveri, R.: Evaluating simulated primary anthropogenic and biomass burning organic aerosols during MILAGRO: implications for assessing treatments of secondary organic aerosols, Atmos. Chem. Phys., 9, 6191-6215, doi:10.5194/acp-9-6191-2009, 2009.

Freitas, S. R., Longo, K. M., Alonso, M. F., Pirre, M., Marecal, V., Grell, G., Stockler, R., Mello, R. F., and Sánchez Gácita, M.: PREP-CHEM-SRC - 1.0: a preprocessor of trace gas and aerosol emission fields for regional and global atmospheric chemistry models, Geosci. Model Dev., 4, 419-433, doi:10.5194/gmd-4419-2011, 2011.

Ge, J. M., Su, J., Ackerman, T. P., Fu, Q., Huang, J. P., and Shi, J. S.: Dust aerosol optical properties retrieval and radiative forcing over northwestern China during the 2008 ChinaU.S. joint field experiment, J. Geophys. Res., 115, D00K12, doi:10.1029/2009JD013263, 2010.

Ghan, S. J. and Zaveri, R. A.: Parameterization of optical properties for hydrated internally mixed aerosol, J. Geophys. Res., 112, D10201, doi:10.1029/2006JD007927, 2007.

Giles, D. M., Holben, B. N., Eck, T. F., Sinyuk, A., Smirnov, A., Slutsker, I., Dickerson, R. R., Thompson, A. M., and Schafer, J. S.: An analysis of AERONET aerosol absorption properties and classifications representative of aerosol source regions, J. Geophys. Res., 117, D17203, doi:10.1029/2012JD018127, 2012.

Ginoux, P., Chin, M., Tegen, I., Prospero, J. M., Holben, B., Dubovik, O., and Lin, S.: Sources and distributions of dust aerosols simulated with the GOCART model, J. Geophys. Res., 106, 20225-20273, 2001.

Grell, G. A. and Devenyi, D.: A generalized approach to parameterizing convection combining ensemble and data assimilation techniques, Geophys. Res. Lett., 29, 1693,
doi:10.1029/2002GL015311, 2002.

Grell, G. A., Peckham, S. E., Schmitz, R., McKeen, S. A., Frost, G., Skamarock, W. C., and Eder, B.: Fully coupled "online" chemistry within the WRF model, Atmos. Environ., 39, 6957-6975, 2005.

Han, X., Zhang, M., Han, Z., Xin, J., and Liu, X.: Simulation of aerosol direct radiative forcing with RAMSCMAQ in East Asia, Atmos. Environ., 45, 6576-6592, doi:10.1016/j.atmosenv.2011.08.006, 2011.

Holben, B. N., Eck, T. F., Slutsker, I., Tanr' e, D., Buis, J. P.,Stezer, A., Vermote, E., Reagan, Y., Kaufman, U. J., Nakajima, T., Lavenu, F., Jankowiak, I., and Smirnov, A.: AERONET-A federated instrument network and data archive for aerosol characterization, Remote Sens. Environ., 66, 1-16, 1998.

Janjic, Z. I.: The surface layer in the NCEP Eta Model, Eleventh Conference on Numerical Weather Prediction, Norfolk, VA, 1923 August; Amer. Meteor. Soc., Boston, MA, 354-355, 1996.

Janjic, Z. I.: Nonsingular Implementation of the Mellor-Yamada Level 2.5 Scheme in the NCEP Meso model, NCEP Office Note, No. 437, 61 pp., http://www.emc.ncep.noaa.gov/ officenotes/newernotes/on437.pdf, 2001.

Jiang, H., Farrar, J. T., Beardsley, R. C., Chen, R., and Chen, C.: Zonal surface wind jets across the Red Sea due to mountain gap forcing along both sides of the Red Sea, Geophys. Res. Lett., 36, L19605, doi:10.1029/2009GL040008, 2009.

Johnson, M. S., Meskhidze, N., Kiliyanpilakkil, V. P., and Gassó, S.: Understanding the transport of Patagonian dust and its influence on marine biological activity in the South Atlantic Ocean, Atmos. Chem. Phys., 11, 2487-2502, doi:10.5194/acp-11-24872011, 2011.

Kaufman, Y. J., Tanre, D., Remer, L. A., Vermote, E. F., Chu, A., and Holben, B. N.: Operational remote sensing of tropospheric aerosol over land from EOS moderate resolution imaging spectroradiometer, J. Geophys. Res., 102, 17051-17067, 1997.

King, M. D., Kaufman, Y. J., Menzel, W. P., and Tanre, D.: Remote sensing of cloud, aerosol, and water vapor properties from the Moderate Resolution Imaging Spectrometer (MODIS), IEEE Trans. Geosci. Remote Sensing, 30, 1-27, 1992.

Laurent, B., Marticorena, B., Bergametti, G., and Mei, F.: Modeling mineral dust emissions from Chinese and Mongolian deserts, Global Planet. Change, 52, 121-141, 2006.

Li, F. and Ramanathan, V.: Winter to summer monsoon variation of aerosol optical depth over the tropical Indian Ocean, J. Geophys. Res., 107, 4284, doi:10.1029/2001JD000949, 2002.

Liao, H. and Seinfeld, J. H.: Radiative forcing by mineral dust aerosols: sensitivity to key variables, J. Geophys. Res., 103, 31637-31646, doi:10.1029/1998JD200036, 1998.

Lin, Y. L., Farley, R. D., and Orville, H. D.: Bulk parameterization of the snow field in a cloud model, J. Climate Appl. Meteor., 22, 1065-1092, 1983.

Liu, J., Zheng, Y., Li, Z., Flynn, C., Welton, E. J., and Cribb, M.: Transport, vertical structure and radiative properties of dust events in southeast China determined from ground and space sensors, Atmos. Environ., 45, 6469-6480, doi:10.1016/j.atmosenv.2011.04.031, 2011.

Mallet, M., Tulet, P., Serça, D., Solmon, F., Dubovik, O., Pelon, J., Pont, V., and Thouron, O.: Impact of dust aerosols on the radiative budget, surface heat fluxes, heating rate profiles and convective activity over West Africa during March 2006, Atmos. Chem. 
Phys., 9, 7143-7160, doi:10.5194/acp-9-7143-2009, 2009.

McFarlane, S. A., Kassianov, E. I., Barnard, J., Flynn, C., and Ackerman, T. P.: Surface shortwave aerosol radiative forcing during the Atmospheric Radiation Measurement Mobile Facility deployment in Niamey, Niger, J. Geophys. Res., 114, D00E06, doi:10.1029/2008JD010491, 2009.

McKeen, S. A., Wotawa, G., Parrish, D. D., Holloway, J. S., Buhr, M. P., Hubler, G., Fehsenfeld, F. C., and Meagher, J. F.: Ozone production from Canadian wildfires during June and July of 1995, J. Geophys. Res., 107, 4192, doi:10.1029/2001JD000697, 2002.

McKendry, I. G., Strawbridge, K. B., O’Neill, N. T., Macdonald, A. M., Liu, P. S. K., Leaitch,W. R., Anlauf, K. G., Jaegle, L., Fairlie, T. D., and Westphal, D. L.: Trans-Pacific transport of Saharan dust to Western North America: a case study, J. Geophys. Res., 112, D01103, doi:10.1029/2006JD007129, 2007.

Miller, R. L., Tegen, I., and Perlwitz, J.: Surface radiative forcing by soil dust aerosols and the hydrologic cycle, J. Geophys. Res., 109, D04203, doi:10.1029/2003JD004085, 2004.

Mlawer, E. J., Taubman, S. J., Brown, P. D., Iacono, M. J., and Clough, S. A.: RRTM, a validated correlated-k model for the longwave, J. Geophys. Res., 102, 16663-16682, 1997.

Osborne, S. R., Johnson, B. T., Haywood, J. M., Baran, A. J., Harrison, A. J., and McConnell, C. L.: Physical and optical properties of mineral dust aerosol during the Dust and Biomass-burning Experiment, J. Geophys. Res., 113, D00C03, doi:10.1029/2007JD009551, 2008.

Papayannis, A., Balis, D., Amiridis, V., Chourdakis, G., Tsaknakis, G., Zerefos, C., Castanho, A. D. A., Nickovic, S., Kazadzis, S., and Grabowski, J.: Measurements of Saharan dust aerosols over the Eastern Mediterranean using elastic backscatter-Raman lidar, spectrophotometric and satellite observations in the frame of the EARLINET project, Atmos. Chem. Phys., 5, 2065-2079, doi:10.5194/acp-5-2065-2005, 2005.

Prospero, J. M.: Saharan dust transport over the North Atlantic Ocean and Mediterranean: An overview, in: The Impact of Desert Dust Across the Mediterranean, edited by: Guerzoni, S. and Chester, R., Kluwer Acad., Norwell, Mass., 133-151, 1996.

Prospero, J. M., Ginoux, P., Torres, O., Nicholson, S. E., and Gill, T. E.: Environmental characterization of global sources of atmospheric soil dust identified with the Nimbus 7 Total Ozone Mapping Spectrometer (TOMS) absorbing aerosol product, Rev. Geophys., 40, 2-1-2-31, 2002.

Raitsos, D. E., Hoteit, I., Prihartato, P. K, Chronis, T., Triantafyllou, G., and Abualnaja, Y.: Abrupt warming of the Red Sea, Geophys. Res. Lett., 38, L14601, doi:10.1029/2011GL047984, 2011.

Randerson, J. T., Van der Werf, G. R., Giglio, L., Collatz, G. J., and Kasibhatla., P. S.: Global Fire Emissions Database, Version 2 (GFEDv2.1), available at: http://daac.ornl.gov/ from Oak Ridge National Laboratory Distributed Active Archive Center, Oak Ridge, Tennesse, USA, doi:10.3334/ORNLDAAC/849, 2005.

Remer, L. A., Kleidman, R. G., Levy, R. C., Kaufman, Y. J., Tanre, D., Mattoo, S., Martins, J. V., Ichoku, C., Koren, I., Yu, H., and Holben, B. N.: Global aerosol climatology from the MODIS satellite sensors, J. Geophys. Res., 113, D14S07, doi:10.1029/2007JD009661, 2008.

Salomonson, V., Barnes, W., Maymon, P., Montgomery, H., and Ostrow, H.: MODIS: Advanced facility instrument for studies of the Earth as a system, IEEE Trans. Geosci. Remote Sens., 27, 145-
153, 1989.

Santese, M., De Tomasi, F., and Perrone, M. E.: Moderate Resolution Imaging Spectroradiometer (MODIS) and Aerosol Robotic Network (AERONET) retrievals during dust outbreaks over the Mediterranean, J. Geophys. Res., 112, D18201, doi:10.1029/2007JD008482, 2007.

Satheesh, K. and Moorthy, K. K.: Radiative effects of natural aerosols: A review, Atmos. Environ., 39, 2089-2110, 2005.

Satheesh, S. K., Moorthy, K. K., Kaufman, Y. J., and Takemura, T.: Aerosol optical depth, physical properties and radiative forcing over the Arabian Sea, Meteorological Atmospheric Physics, 91, 45-62, doi:10.1007/S00703-004-0097-4, 2006.

Schell, B., Ackermann, I. J., Hass, H., Binkowski, F. S., and Ebel, A.: Modeling the formation of secondary organic aerosol within a comprehensive air quality modeling system, J. Geophys. Res., 106, 28275-28293, 2001.

Seinfeld, J. H., Carmichael, G., Arimoto, R., Conant, W. C., Brechtel, F. J., Bates, T. S., Cahill, T. A., Clarke, A. D., Doherty, S. J., Flatau, F. J., Huebert, B. J., Kim, J., Markowicz, K. M., Quinn, P. K., Russell, L. M., Russell, P. B., Shimizu, A., Shinozuka, Y., Song, C. H., Tang, Y., Uno, I., Vogelmann, A. M., Weber, R. J., Woo, J., and Zhang, X. Y.: ACE-ASIA, Regional climatic and atmospheric chemical effects of Asian dust and pollution, B. Am. Meteor. Soc., 85, 367-380, 2004.

Skamarock, W. C., Klemp, J. B., Dudhia, J., Gill, D. O., Barker, D. M., Wang, W., and Powers, J. G.: A description of the advanced research WRF version 2, NCAR Tech. Note, NCAR/TN468+STR, Natl. Cent. for Atmos. Res., Boulder, Colo, available at: http://wrf-model.org/wrfadmin/publications.php (last access: October 2012), 2008.

Slingo, A., Ackerman, T. P., Allan, R. P., Kassianov, E. I., McFarlane, S. A., Robinson, G. J., Barnard, J. C., Miller, M. A., Harries, J. E., Russell, J. E., and Dewitte, S.: Observations of the impact of a major Saharan dust storm on the atmospheric radiation balance, Geophys. Res. Lett., 33, L24817, doi:10.1029/2006GL027869, 2006.

Stenchikov, G. L., Kirchner, I., Robock, A., Graf, H., Antuña, J. C., Grainger, R. G., Lambert, A., and Thomason, L.: Radiative forcing from the 1991 Mount Pinatubo volcanic eruption, J. Geophys. Res., 103, 13837-13857, 1998.

Stockwell, W. R., Middleton, P., and Chang, J. S.: The second generation regional acid deposition model chemical mechanism for regional air quality modeling, J. Geophys. Res., 95, 16343-16367, 1990.

Tanre, D., Kaufman, Y. J., Herman, M., and Mattoo, S., Remote sensing of aerosol properties over oceans using the MODIS/EOS spectral radiances, J. Geophys. Res., 102, 1697116988, doi:10.1029/96JD03437, 1997.

Watson, A. J., Bakker, D. C. E., Ridgwell, A. J., Boyd, P. W., and Law, C. S.: Effect of iron supply on Southern Ocean CO2 uptake and implications for glacial atmospheric $\mathrm{CO}_{2}$, Nature, 407, 730 733, 2000.

Weikert H.: Plankton and the pelagic environment, in: Key Environments, Red Sea, edited by: Edwards, A. J. and Head, S. M., Pergamon Press, Oxford, 90-111, 1987.

Weinzierl, B., Petzold, A., Esselborn, M., Wirth, M., Rasp, K., Kandler, K., Schutz, L., Koepke, P., and Fiebig, M.: Airborne measurements of dust layer properties, particle size distribution and mixing state of Saharan dust during SAMUM 2006, Tellus B, 61, 
96-117, doi:10.1111/j.1600-0889.2008.00392.x, 2009.

Weinzierl, B., Sauer, D., Esselborn, 5 M., Petzold, A., Veira, A., Rose, M., Mund, S., Wirth, M.,Ansmann, A., Tesche, M., Gross, S., and Freudenthaler, V.: Microphysical and optical properties of dust and tropical biomass burning aerosol layers in the Cape Verde region - an overview of the airborne in situ and lidar measurements during SAMUM-2, Tellus B, 63, 589-618, doi:10.1111/j.1600-0889.2011.00566.x, 2011.

Zender, C. S., Tegen, I., and Miller, R.,: Quantifying mineral dust mass budgets: terminology, constraints, and current estimates, Eos, 85, p. 509, doi:10.1029/2004EO480002, 2004.

Zhao, C., Liu, X., Leung, L. R., Johnson, B., McFarlane, S. A., Gustafson Jr., W. I., Fast, J. D., and Easter, R.: The spatial distribution of mineral dust and its shortwave radiative forcing over North Africa: modeling sensitivities to dust emissions and aerosol size treatments, Atmos. Chem. Phys., 10, 8821-8838, doi:10.5194/acp-10-8821-2010, 2010.
Zhao, C., Liu, X., Ruby Leung, L., and Hagos, S.: Radiative impact of mineral dust on monsoon precipitation variability over West Africa, Atmos. Chem. Phys., 11, 1879-1893, doi:10.5194/acp11-1879-2011, 2011.

Zhao, C., Liu, X., and Leung, L. R.: Impact of the Desert dust on the summer monsoon system over Southwestern North America, Atmos. Chem. Phys., 12, 3717-3731, doi:10.5194/acp-12-37172012, 2012.

Zhang, J., Liu, S. M., Lu, X., and Huang, W. W.: Characterizing Asian wind-dust transport to the Northwest Pacific Ocean. Direct measurements of the dust flux for two years, Tellus B, 45, 335345, doi:10.1034/j.1600-0889.1993.t01-3-00003.x, 1993.

Zhang, X. Y., Arimoto, R., and An, Z. S.: Dust emission from Chinese desert sources linked to variations in atmospheric circulation, J. Geophys. Res., 102, 28041-28047, 1997.

Zhang Y., Duliere, V., Mote, P. W., and Salathe Jr., E. P.: Evaluation of WRF and HadRM Mesoscale Climate Simulations over the U.S. Pacific Northwest, J. Climate, 22, 5511-5526, doi:10.1175/2009JCLI2875.1, 2009. 